\title{
The Evolving Market Structure of the U.S. Residential Solar PV Installation Industry, 2000-2016
}

Eric O'Shaughnessy

National Renewable Energy Laboratory
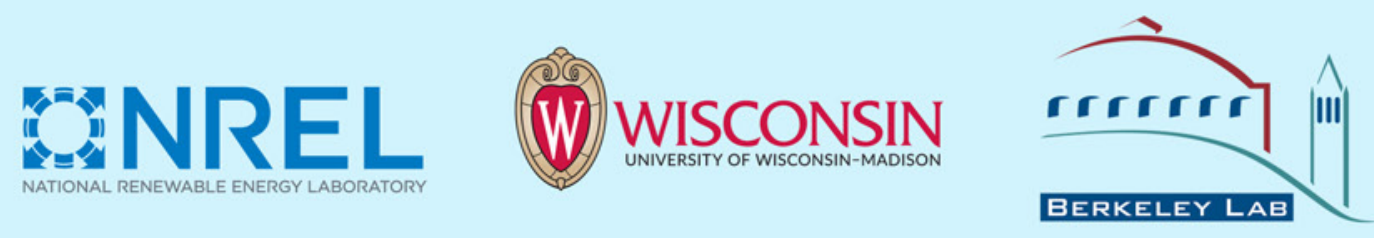

January 2018

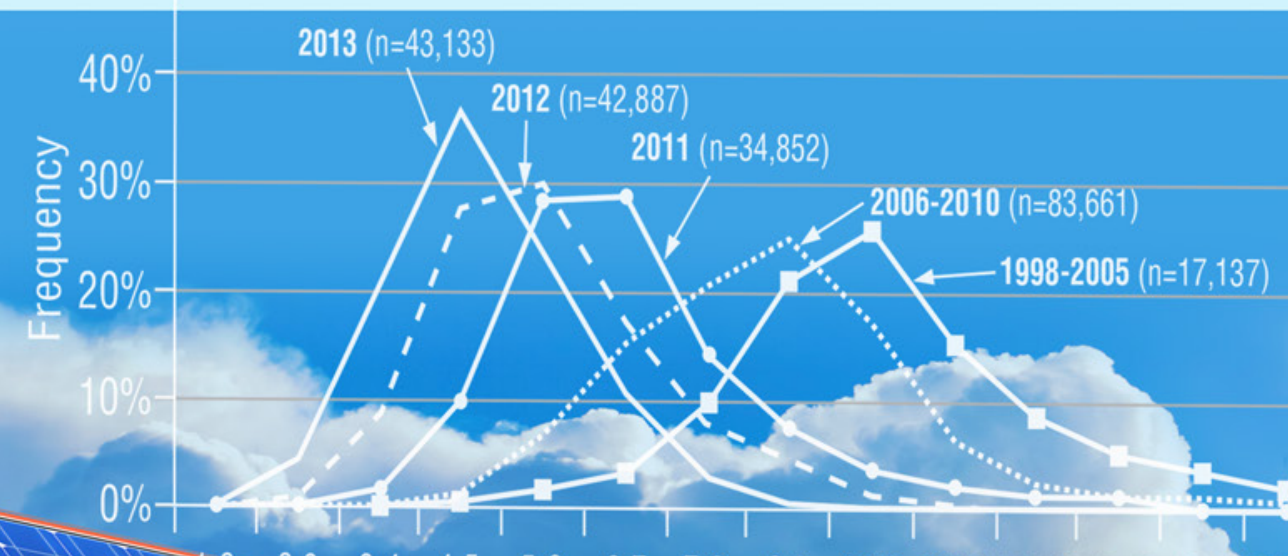

\section{$2013(n=43,133)$}

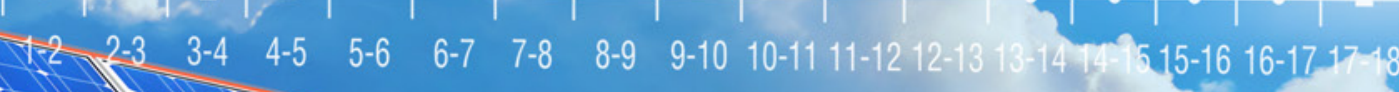
Installed Price $\left(2013 \$ / W_{D C}\right)$

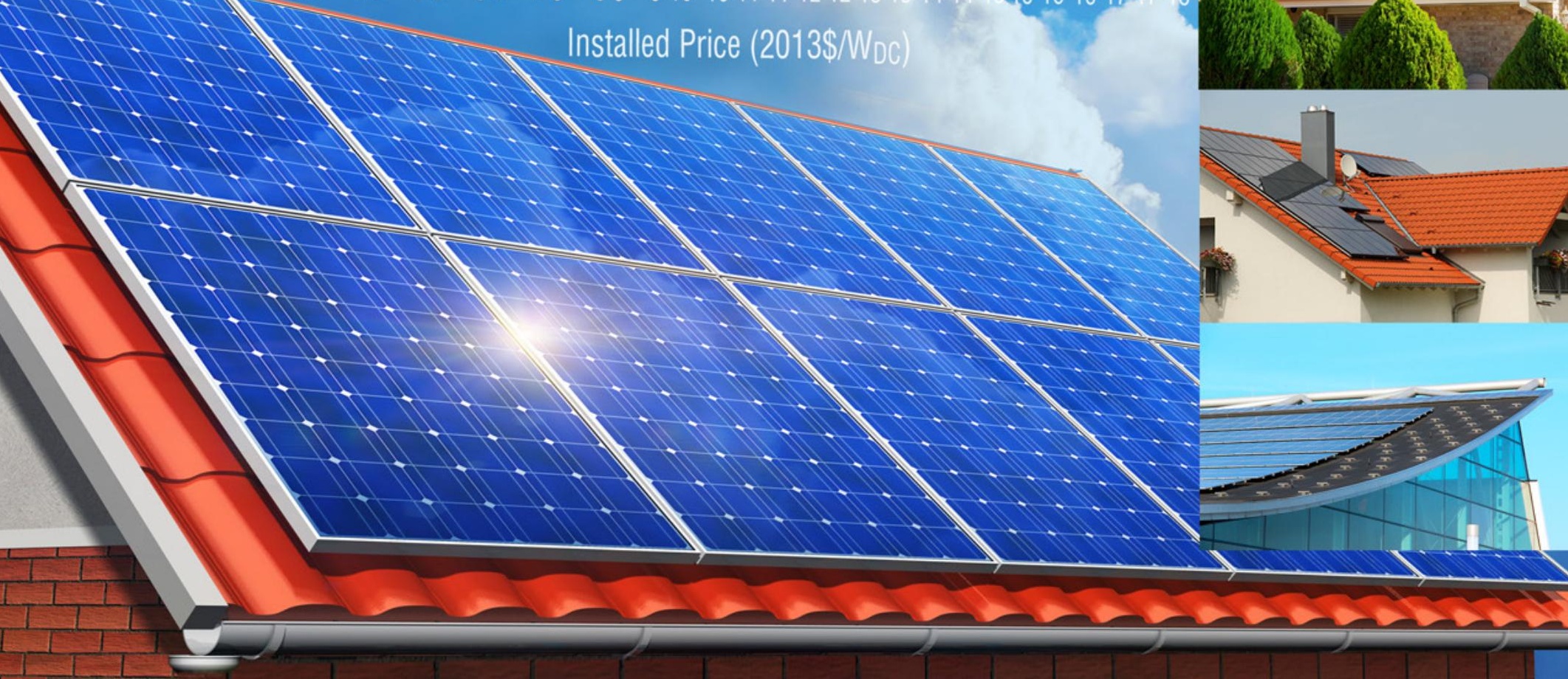




\section{The Evolving Market Structure of the U.S. Residential Solar PV Installation Industry, 2000-2016}

\section{Eric 0'Shaughnessy}

National Renewable Energy Laboratory

\section{Contents}

Executive Summary iv

1 Introduction... 1

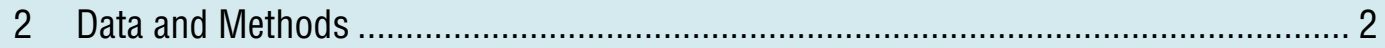

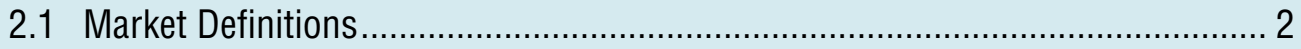

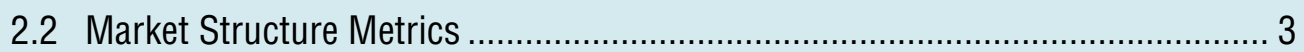

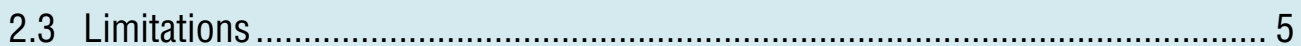

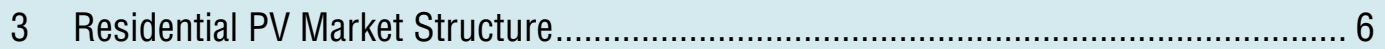

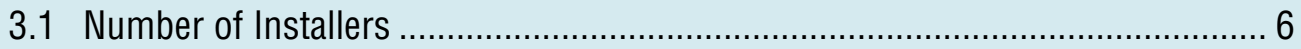

3.2 Market Concentration.............................................................................. 8

4 Role of Customer Financing in the Evolving PV Market Structure ............................. 14

4.1 Background: Customer Financing Options .................................................. 14

4.2 Analysis: Relationship Between Market Structure and Customer Finance ......... 15

5 Discussion and Conclusion ................................................................................. 20

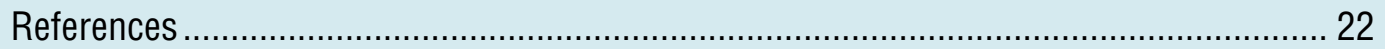

\section{List of Figures}

Figure ES-1. Number of active installers by year (left) and market shares of 10, 20, and 50 highest-volume installers (right), 2000-2016

Figure 1. Visualization of local residential PV installation markets in Los Angeles County

Figure 2. Lorenz curve examples

Figure 3. Number of installers, 2000-2016

(inset depicts number of systems installed)

Figure 4. Market entry, exit, and incumbency, 2000-2016 ..........................................7

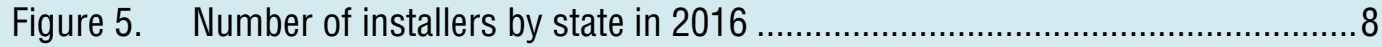

Figure 6. Residential PV Lorenz curves over time for the national market ......................9

Figure 7. Market shares of highest-volume 10, 20, and 50 installers, 2000-2016..........9

Figure 8. Market shares of highest-volume 5 and 10 installers by state, for the eight states with the most installations in the data set, 2008-2016 


\section{List of Figures (cont.)}

Figure 9. Residential PV installation industry HHI, 2000-2016

Figure 10. HHI for the eight states with the most

installations in the data set, 2008-2016

Figure 11. HHI for the eight counties with the most installations in the data set, 2008-2016

Figure 12. $\mathrm{HHI}$ for the eight local markets with the most installations in the data set, 2008-2016

Figure 13. HHI changes by local market from 2012 to 2015 (left) and from 2015 to 2016 (right)

Figure 14. Number of installers using the TP0 model by year, 2000-2016 16

Figure 15. HHI and \%TPO, 2000-2016 17

Figure 16. $\mathrm{HHI}$ and \%TPO by state, 2008-2016 17

Figure 17. $\mathrm{HHI}$ and \%TPO by local market, 2008-2016 18

Figure 18. HHI for TPO and non-TPO systems (left) and in high- and low-TPO states (right)

Figure 19. Lorenz curves for TPO and non-TPO systems 19

Figure 20. Market shares of all installers active before 2013 (left) and annual installation volumes of those installers outside the highest-volume 100 (right)
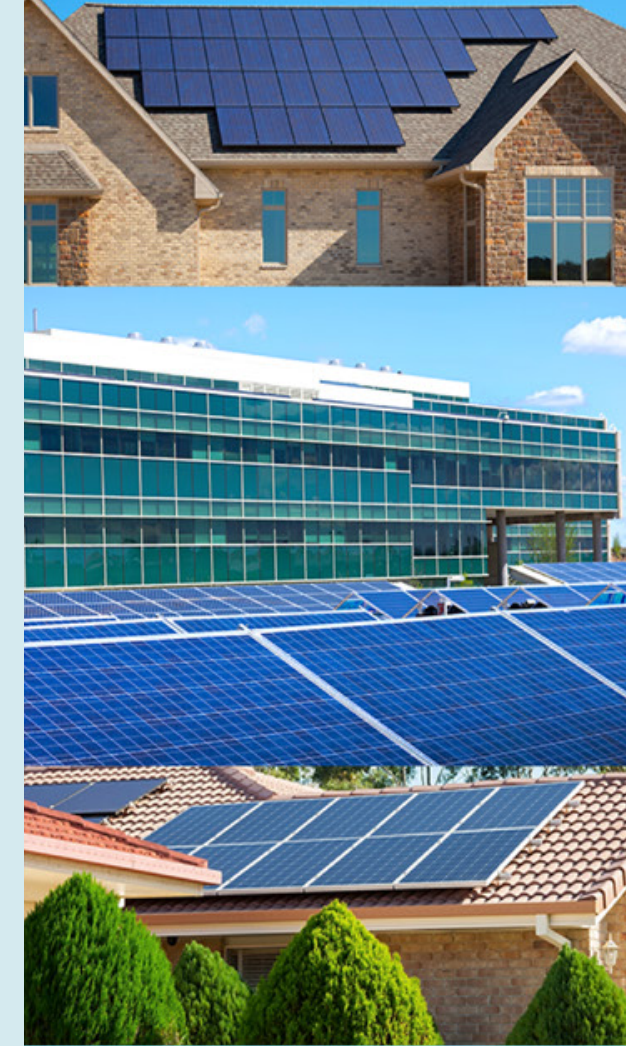

$=$

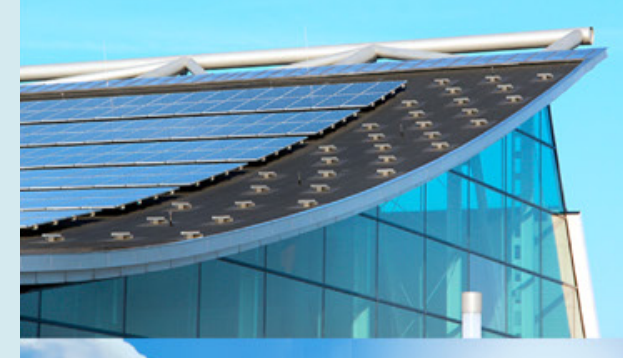




\section{Executive Summary}

The U.S. residential solar photovoltaic (PV) installation industry is evolving in terms of market structure - the number of installation companies (installers) and the distribution of market shares of those installers. This study explores the evolving market structure. Long-term trends in residential PV market structure are presented using a data set of nearly one million residential PV systems installed from 2000 to 2016.

About 8,700 different companies installed at least one residential PV system from 2000 to 2016, with about 2,900 installers being active in 2016 (Figure ES-1, left). About half of these companies installed fewer than five systems, and many companies may represent firms from related industries (e.g., electrical contracting) that install PV as a side business. At the same time, more than 800 companies have installed more than 100 residential PV systems, and more than 100 companies have installed more than 1,000 systems.

The U.S. residential PV installation industry became less concentrated from 2000 through about 2010 as a large number of installers entered the growing market. From 2010 to 2016, the industry became increasingly concentrated as a subset of high-volume installers accumulated a disproportionately large market share (Figure ES-1, right). Increasing market concentration has occurred at every market level, from national to state and local markets. The period of increasing market concentration occurred concurrently with — and may have contributed to - a period of significant market growth overall. As a result, increasing market concentration has generally not occurred at the expense of lower-volume companies. High-volume companies have increased market share, but lower-volume companies have also increased sales in the growing market.
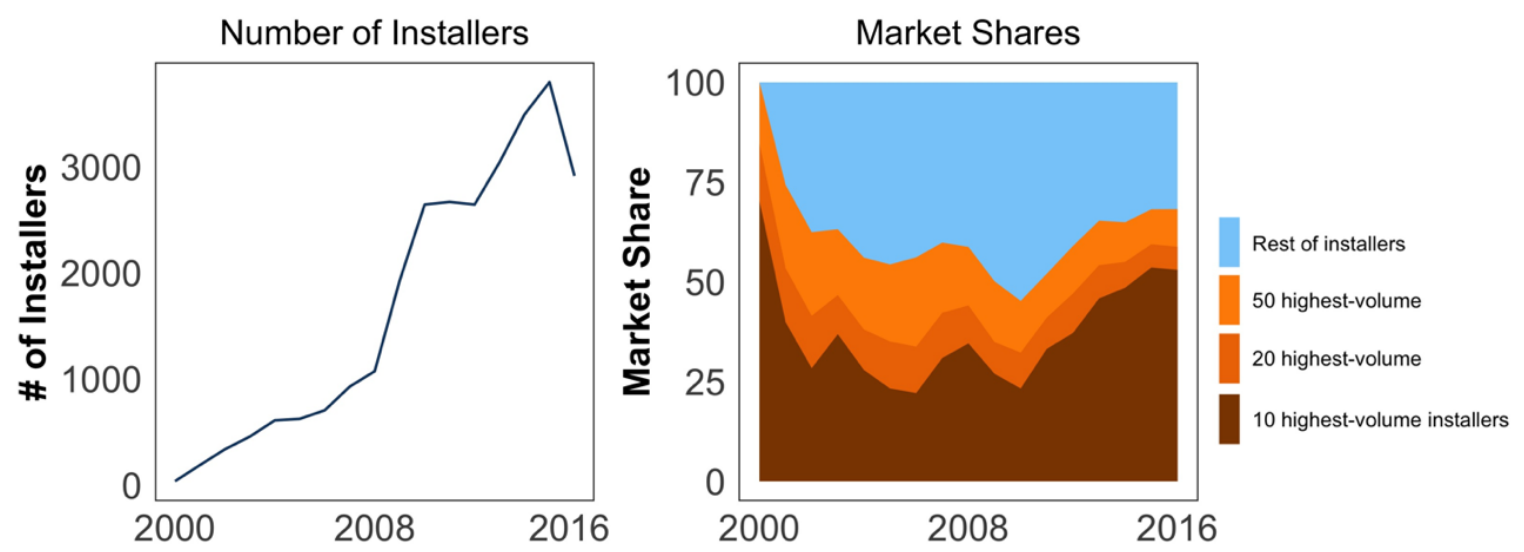

Figure ES-1. Number of active installers by year (left) and market shares of 10, 20, and 50 highestvolume installers (right), 2000-2016

There are several possible explanations for increasing market concentration in the U.S. residential PV installation industry. In this study, the connection between increasing concentration and the emergence of third-party ownership (TPO) customer financing models is explored. High-volume installers are more likely to offer TPO products than are low-volume installers. Hence, the increasing popularity of TPO products from 2010 to 2016 likely facilitated market concentration. As evidence of this relationship, sales of customer-owned systems did not exhibit the same degree of market concentration as did sales of TPO systems over the study period. The implications of market concentration are an ongoing area of research. 


\section{Introduction}

Market structure describes the organization of firms within a given industry. It is of interest to policymakers and researchers owing to the relationships among competition, prices, and innovation. The number of firms and the distribution of market shares among those firms determine an industry's competitive intensity. In turn, the degree of competitive intensity determines the pressures on firms to innovate, reduce costs, and offer lower prices (Tirole 1988).

In the context of the U.S. residential solar photovoltaic (PV) installation industry, stakeholders are interested in how market structure affects installed PV system prices and PV adoption (e.g., Gillingham et al. 2016; Nemet et al. 2017; Pless et al. 2017). High installed prices have posed the key barrier to large-scale residential PV deployment. Significant price reductions over the past two decades have driven a rapidly expanding residential PV market. This price decline is associated primarily with falling PV hardware costs. Non-hardware or "soft" costs —including installation costs - now constitute a larger share of PV price stacks than in previous years (Barbose and Darghouth 2017; Fu et al. 2017).

Market structure affects these soft costs by determining installers' incentives to reduce profit margins and installation costs and thus offer lower-priced systems. As a result, market structure can impede or facilitate future soft cost and installed price reductions. Studies to date have described PV market structure at a high level based on limited data sets, showing that - among the thousands of U.S. residential PV installation companies - a subset of high-volume companies accounts for a large proportion of installations (Fu et al. 2017; Litvak 2017; Perea et al. 2017).

This study provides a more granular depiction of the evolving U.S. PV market structure by applying a rich data set of nearly one million residential PV installations. ${ }^{1}$ The aim is to provide a benchmark of the key trends in residential PV market structure from 2000 to 2016. Several metrics and visualization methods show how the industry has changed over time in terms of the number of installation firms, rates of market entry and exit, and distribution of market shares among installers. Descriptive analyses are also provided to explain these trends. However, the results do not include evaluation of the effects of market structure trends on industry competition, prospects, and so forth; the implications of the observed trends will be examined in future research.

The remainder of this report is organized as follows. Section 2 describes the data and methods used for the study. Section 3 summarizes market structure trends in the U.S. residential PV industry in terms of number of installers and market concentration. Section 4 presents a descriptive analysis of the relationship between PV market structure and recent trends in customer financing options. Section 5 summarizes key findings.

\footnotetext{
${ }^{1}$ This report is part of a larger body of research conducted by Lawrence Berkeley National Laboratory, University of Texas at Austin, University of Wisconsin-Madison, the National Renewable Energy Laboratory, and Yale University. The research more broadly explores PV system price variability in the United States.
} 


\section{Data and Methods}

The study data are from Lawrence Berkeley National Laboratory's Tracking the Sun (TTS) data set, which consists of installed PV system data from more than 60 PV incentive and interconnection programs (Barbose and Darghouth 2017). The data set includes installer names for more than 930,000 residential PV systems installed from 2000 to 2016 and which represented about $70 \%$ of the U.S. market. ${ }^{2}$

The raw reported data consist of more than 30,000 unique installer names. However, most reported names are variants of other installer names or reporting errors. For instance, a company such as "Blue Solar" may be listed as "Blue Solar Company" (variant) and "Blue Soolar" (typo). In these cases, all installer names were changed to a single base name (e.g., "Blue Solar"). Other cases of duplication required additional judgment. For instance, "Blue Solar" and "Blue Solar \& Electric" may or may not be two different companies. Such close name matches were addressed through an additional geographic criterion. If two close name matches shared the same modal county (the county where the named installer installed the most systems), the close names were changed to a single base name. Otherwise the close names were treated as separate companies. When necessary, additional web searches supplemented the name-matching process.

Finally, personal names (e.g., John Smith) were commonly reported as installers on incentive applications. When personal names were reported for multiple systems, it was assumed that the personal name represented an actual installer. When a unique personal name was reported for a single system, it was difficult to conclude whether the name represented an actual installer, an employee of an installation company, or a homeowner who self-installed the system; the 451 names of this type were treated as missing values and dropped from the data set.

The TTS data set consists of 938,955 systems installed between 2000 and 2016. After data cleaning, the number of unique installer names dropped from more than 30,000 to about 8,700. The data include systems from 20 states, including all major U.S. markets except Hawaii.

\subsection{Market Definitions}

Measurements of market structure are sensitive to the geographic boundaries used to define markets (Stigler and Sherwin 1985; Brooks 1995; Davis and Garces 2010). In this study, market structure results are presented at the national, ${ }^{3}$ state, county, and local levels. Using national, state, and county jurisdictional boundaries as proxies for market boundaries is simple and convenient. In economic theory, however, market boundaries should encompass the area within which the forces of supply and demand determine prices (Stigler and Sherwin 1985). Jurisdictional boundaries often do not coincide with the theoretical boundaries required by economic theory (Brooks 1995). O’Shaughnessy et al. (2016) develop a methodology to delineate residential PV market boundaries based on the spatial distribution of installers; the concept is that the interaction of different local installers shapes the formation of local PV prices

\footnotetext{
2 "Residential" PV systems are defined consistently with previous TTS-related research (Nemet et al. 2017). Here, a PV system is assumed to be residential if it is self-reported as a residential customer or no customer class was reported but the system is smaller than $15 \mathrm{~kW}$.

${ }^{3}$ National samples are not truly national given the limited coverage of TTS. TTS covers most major markets, except Hawaii.
} 
and thus the form of local markets. The outcome of this approach is a set of markets defined by groups of geographically contiguous ZIP codes. For the purposes of this study, these markets are referred to as "local" markets, given that the markets are generally smaller than counties. ${ }^{4}$ When applied to the study data set, this approach generates 961 local markets. As an example, Figure 1 depicts local market boundaries in Los Angeles County.

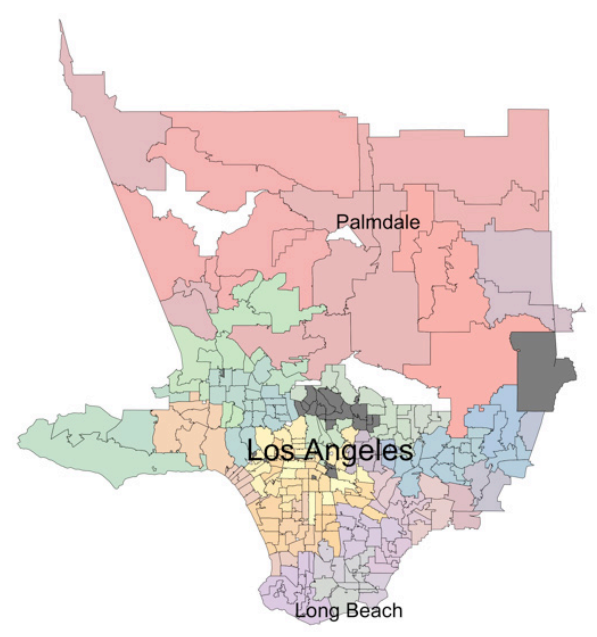

Local markets in Los Angeles County

Each color corresponds to a separate market (white areas have no ZIP code, and dark gray areas are ZIP codes with no data). The local market approach splits Los Angeles County into 57 local markets based on the spatial distribution of installers. Delineating market boundaries below the county level allows increased precision in analysis of local markets. For more information, see O'Shaughnessy et al. (2016).

Figure 1. Visualization of local residential PV installation markets in Los Angeles County

\subsection{Market Structure Metrics}

Four metrics are used to describe market structure: the number of firms, market shares of the highest-volume firms, Lorenz curves, and the Herfindahl-Hirschman index (HHI). For all metrics, an "active" installer refers to a company that installed at least one system in a given period. The number of firms refers to the number of active installers in each year.

Market concentration refers to the degree to which market shares have accumulated with some subset of firms within an industry. A market with many firms with relatively evenly distributed market shares is said to exhibit low market concentration, whereas a market with a few firms controlling disproportionate market shares is said to exhibit high market concentration. A simple measurement of market concentration is the market share of an industry's highest-volume firms. All else being equal, a higher market share among an industry's highest-volume firms reflects a more concentrated industry.

Lorenz curves are a common way to visualize the degree of concentration in a given market. Figure 2 shows examples of Lorenz curves. The horizontal axis ranks installers in terms of market share, with the lowest-volume installers on the left and the highest-volume on the right. The vertical axis depicts the cumulative market shares of the installers. The $45^{\circ}$ line of market parity shows how the distribution would be shaped if all installers split market shares evenly. The gap between the line of market parity and the actual distribution represents the degree of market concentration. Thus, the leftmost plot in Figure 2 depicts full market parity (i.e., all firms

\footnotetext{
${ }^{4}$ The methodology is applied using TTS data from 2015-2016 and a critical "installer overlap coefficient" value of 0.25 with a spatial smoothing technique. See O’Shaughnessy et al. (2016).
} 
have equal market shares). In contrast, the rightmost plot in Figure 2 shows higher market concentration (i.e., a few firms have disproportionately high market shares).
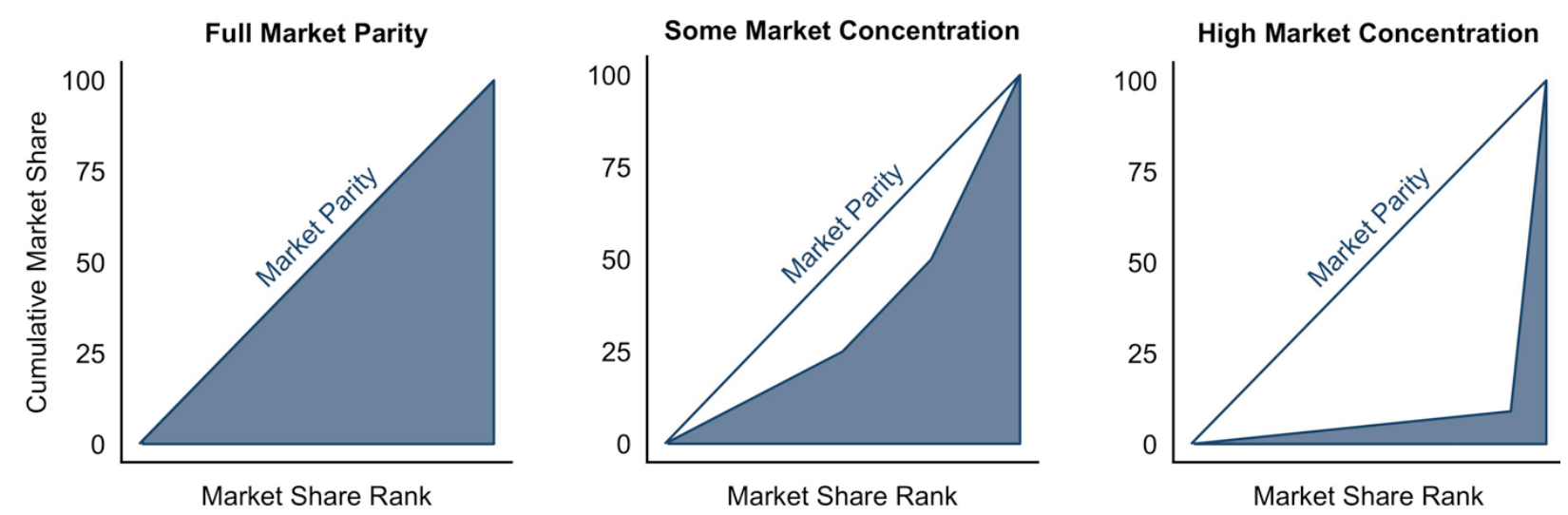

Figure 2. Lorenz curve examples

The HHI provides a numerical value for the degree of market concentration within an industry. The HHI is the sum of the squared market shares of all companies in a given market and period:

$$
H H I_{t}=\sum_{i=1}^{N_{t}}\left(\frac{v_{i t}}{V_{t}}\right)^{2}
$$

Where $\mathrm{HHI}_{t}$ is the $\mathrm{HHI}$ at time $t, N_{t}$ is the number of active firms, $V_{t}$ is the total volume of installations in the period, and $v_{i t}$ is the volume of an individual installer $i$. A low HHI (approaching zero) suggests low market concentration, whereas a high HHI (approaching one) suggests high market concentration.

The four metrics used to describe market structure (number of installers, market shares of highest-volume firms, Lorenz curves, and HHI) do not necessarily provide consistent results when other underlying industry characteristics change. If the distribution of market shares among all firms in an industry is identical, Lorenz curves will depict the industry at market parity regardless of the number of firms. Hence, Lorenz curves fail to convey information about whether an industry is highly competitive (many firms) or oligopolistic (few firms). The market share metric and HHI incorporate the number of firms and will change according to the number of firms in the industry, with higher values of both metrics (more concentration) in industries with fewer firms. However, it can be difficult to determine from these market share metrics whether an industry is concentrated because of a highly skewed distribution of market shares or because the industry is split between few firms. Thus, assessing market structure based on all four metrics provides a more holistic understanding of trends in market structure. 


\subsection{Limitations}

The study data have limitations. First, despite a rigorous installer name cleaning process, it is still likely some installation companies in the data set are duplicates of the same company, and that some single names represent multiple companies. Counts of installers are therefore rounded to two significant digits to avoid overstating the precision of these estimates. Second, the use of installed system data implies that data are only observed for companies that won a bid in any given period. Some companies may have been actively quoting in certain markets in certain periods without installing a system, and thus are not "active" by our data-driven definition. The use of installed systems data rather than quote data is valid for market share calculation but may generally understate the number of active installers. 


\section{Residential PV Market Structure}

This section summarizes residential PV market structure in terms of number of firms (Section 3.1) and market concentration (Section 3.2) over time and space. Most market structure measurements are based on a national market definition unless otherwise noted.

\subsection{Number of Installers}

About 8,700 different companies installed at least one residential PV system from 2000 to 2016 in the U.S. markets covered by the TTS data, with about 2,900 installers being active in 2016 (Figure 3). The number of installers has paralleled the growth in market size overall (Figure 3 inset). Between 2008 and the peak year of 2015, the number of installers grew by about a factor of four, from 1,070 to 3,800. The recent decrease in number of installers coincided with slowing market growth in 2016 overall. ${ }^{5}$ More than half of the drop is attributed to the territory of a single utility: Southern California Edison (SCE). In 2015, the SCE territory led the United States in number of installers, but the numbers of installations and active installers in the SCE territory declined from 2015 to 2016. Although this reduction may reflect an emerging trend, further data are needed to verify that the trend does not reflect underlying data issues. At least part of the drop may be attributed to an approximately 50\% increase in the number of systems reported to SCE without an installer name listed, although this only applies to about $1 \%$ of systems. A similar reduction in number of installers also occurred in other regions of California.

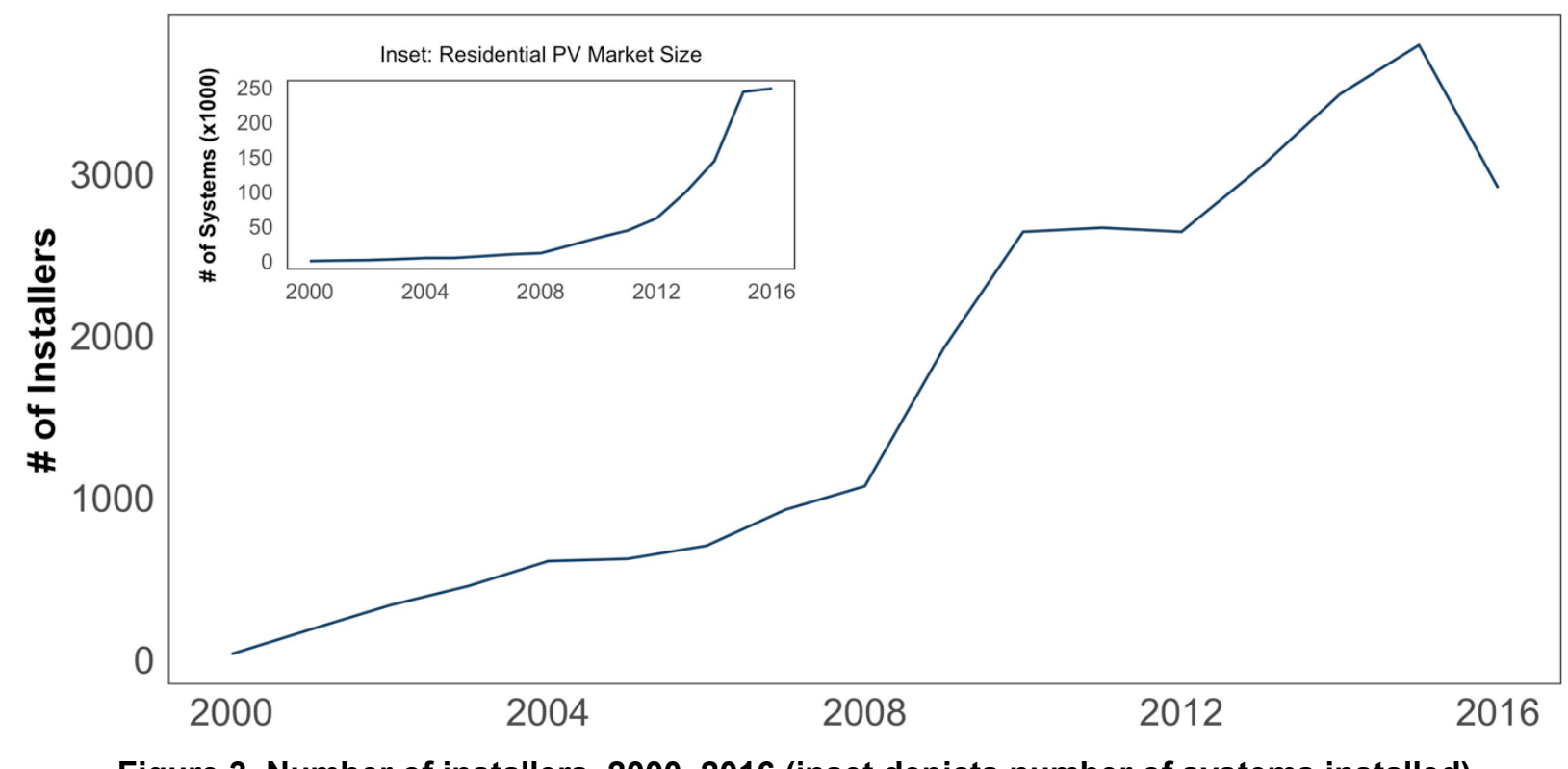

Figure 3. Number of installers, 2000-2016 (inset depicts number of systems installed)

About 2,400 of the 8,700 companies that installed a residential PV system only installed a single system, and more than half (4,700 companies) installed five or fewer systems. Many of these installers were companies from related service industries such as electricians, roofers, and construction contractors that "dabbled" in the residential PV market by installing one or a few systems. Dabblers compete directly with specialized residential PV installers for the same PV

\footnotetext{
${ }^{5}$ Market growth slowed in 2016 in the residential sector, although other studies using different data do not report as significant of a slow-down as indicated by the TTS data (Perea et al. 2017).
} 
customers. Thus, dabblers are treated as PV installers for the purposes of this study. At the same time, the residential PV industry includes a growing base of specialized PV installation companies. In 2016, more than 1,400 companies specialized in PV installation, employing more than 137,000 people (Solar Foundation 2017). ${ }^{6}$

The number of active installers in any given period is a function of market entry (new installers entering the market), incumbency (installers remaining in the market), and exit (installers leaving the market). For the purposes of this study, market entry is measured according to the first year in which an installer installed a system. Market exit is measured as the last year in which an installer installed a system. Installers that entered and exited the market in the same year are counted in both the entry and exit categories. Incumbents in a given year are existing installers that did not either enter or exit the market that year. Observations of market exit are necessarily truncated, given that the data end in 2016 and installer activity is not observed in 2017. For this reason, 2016 data are excluded from Figure 4. From 2000 to 2010, the growth in the number of installers was driven by market entry, with a notable increase in market entry from 2008 to 2010 (Figure 4). Market exits generally correlated with entries, in part owing to dabblers that entered and exited in the same year. Market entry peaked in 2010. The sustained increase in the number of installers from 2012 to 2015 is attributable primarily to incumbency (i.e., more installers remained active in the market rather than dabbling or exiting). Market entry appears to stagnate in 2015.

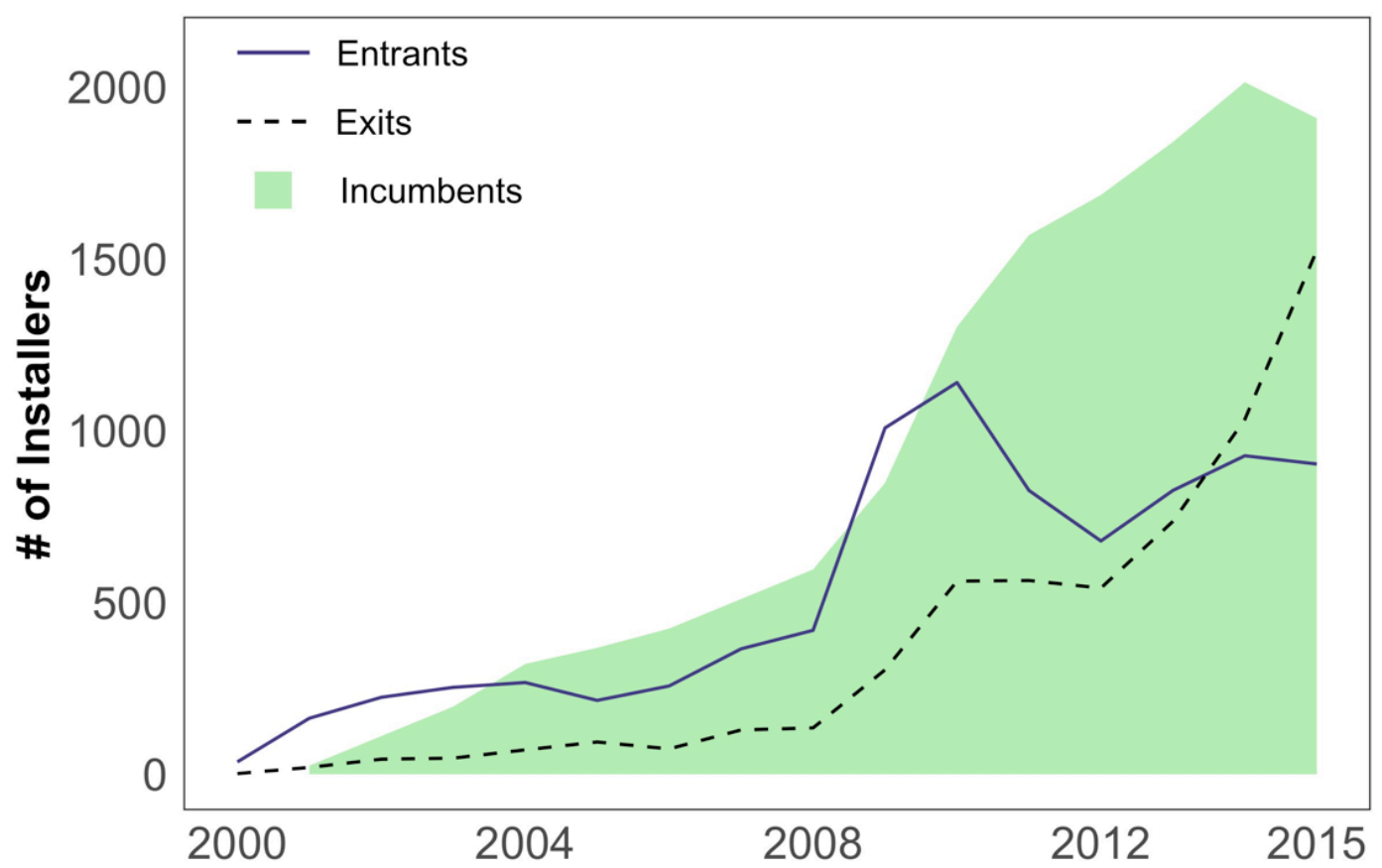

Figure 4. Market entry, exit, and incumbency, 2000-2016 entry $=$ first year with installation, exit $=$ last year with installation

\footnotetext{
${ }^{6}$ The Solar Foundation's estimate includes residential and commercial-scale installers.
} 
As Figure 5 shows, California - which has the largest U.S. residential PV market by far-had the largest installer industry in 2016, with about 2,000 active installers. Among the remaining states, Arizona had the largest number of active installers with about 200, Massachusetts and New Jersey each had about 190, and the other states had substantially fewer.

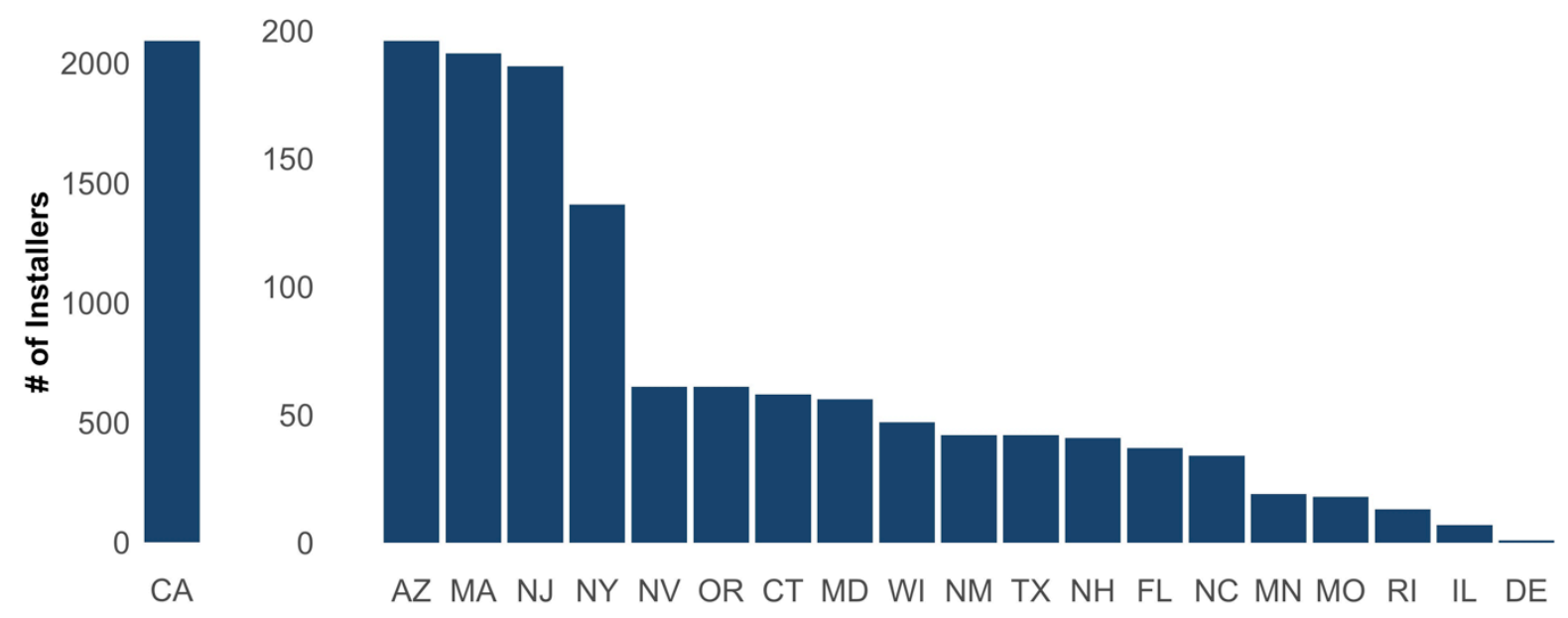

Figure 5. Number of installers by state in 2016

\subsection{Market Concentration}

Figure 6 depicts Lorenz curves over time for the national residential PV market. The Lorenz curves suggest that the U.S. residential PV industry is concentrated (i.e., a subset of high-volume companies has a disproportionately large market share). In 2016, less than $1 \%$ of installers installed more than 1,000 systems, yet these companies accounted for about $60 \%$ of installed systems. At the same time, the clear majority of installers are relatively small, as depicted by the "long tail" of low cumulative market shares in the Lorenz curve. About $61 \%$ of installers installed fewer than 10 systems in 2016. Figure 6 also suggests that the residential PV industry has become more concentrated over time. The market shares of the industry's highest-volume firms grew from 2000 to 2015, pushing the Lorenz curve further away from market parity. This trend reversed slightly in 2016, with high-volume installers losing market share to smaller firms from 2015 to 2016. 


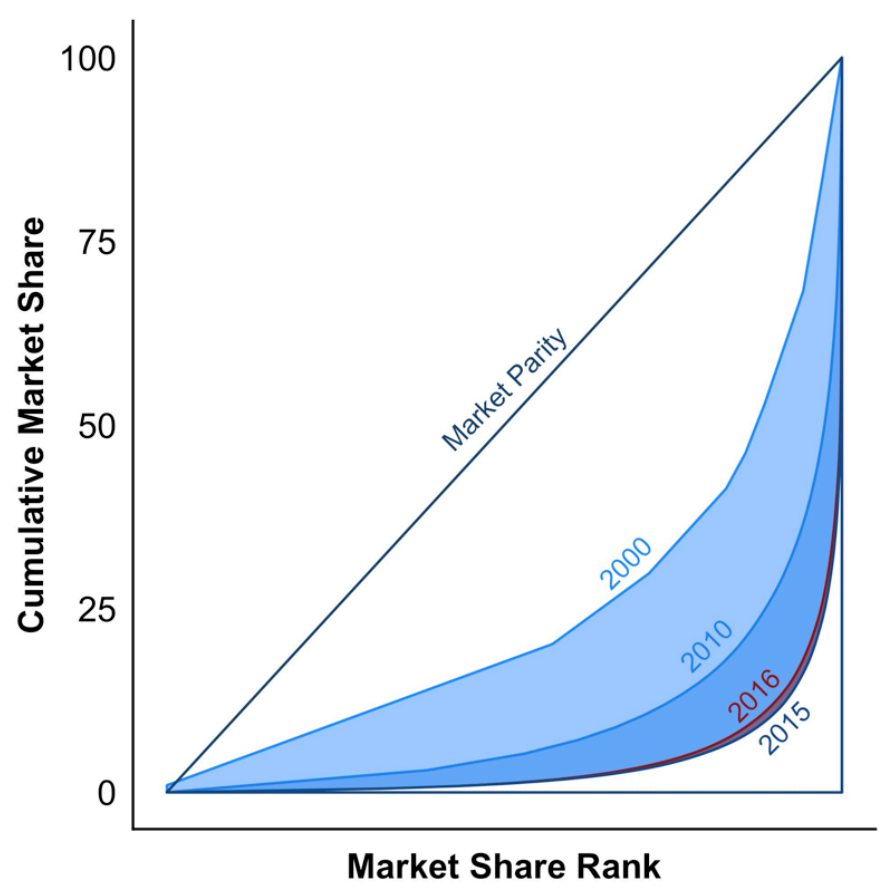

Figure 6. Residential PV Lorenz curves over time for the national market

Figure 7 plots the market shares of the 10,20, and 50 highest-volume installers over time. In the early 2000s, the market shares of the nascent industry's highest-volume installers fell as more competitors entered the market. This trend stabilized by about 2004, although market entry continued (see Figure 4). Beginning around 2010, the industry's highest-volume installers began to increase market share despite continued market entry. In 2010, the industry's 10 highestvolume installers accounted for about 23\% of installed systems. By 2015, the industry's 10 highest-volume installers had increased market share to $54 \%$ of installed systems.

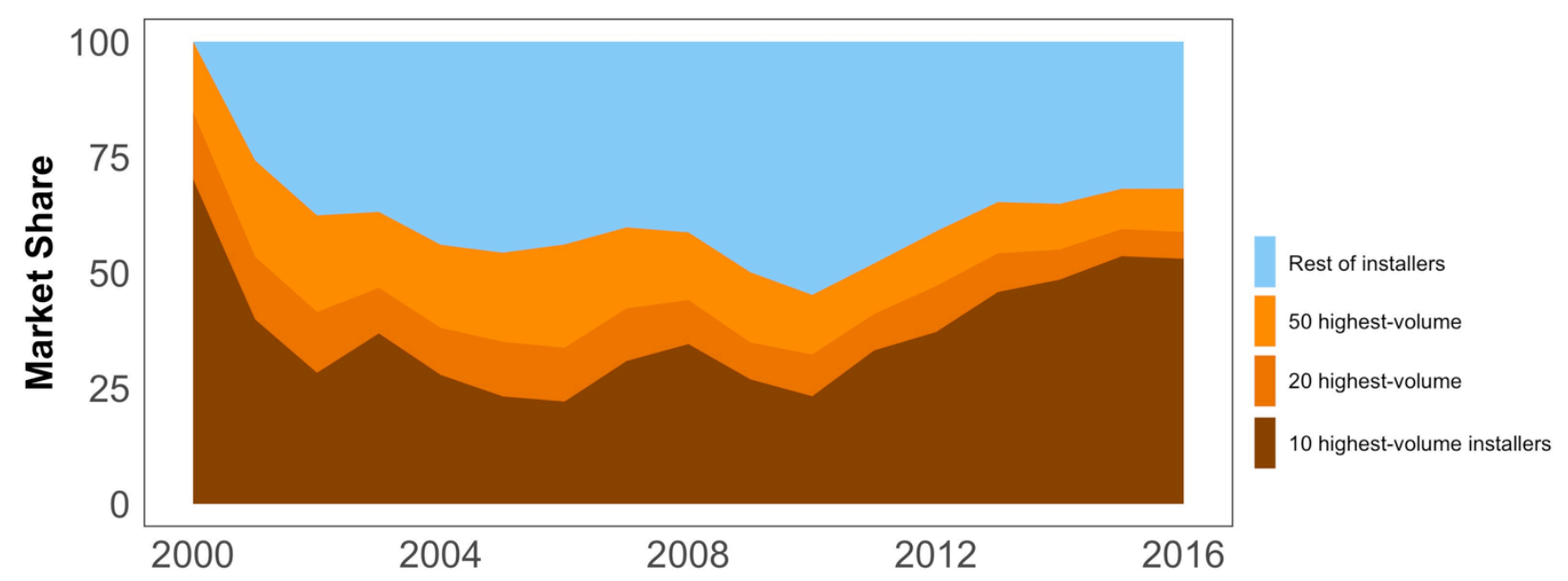

Figure 7. Market shares of highest-volume 10, 20, and 50 installers, 2000-2016 
Figure 8 plots the market shares from 2008 to 2016 for the 5 and 10 highest-volume installers in each state for the eight states with the most installations in the data set. Similar to national trends, markets in all eight states exhibited some period of increasing concentration between 2008 and 2016, although this concentration appears to have lagged several years behind national trends in states like Connecticut, New Jersey, and Nevada.

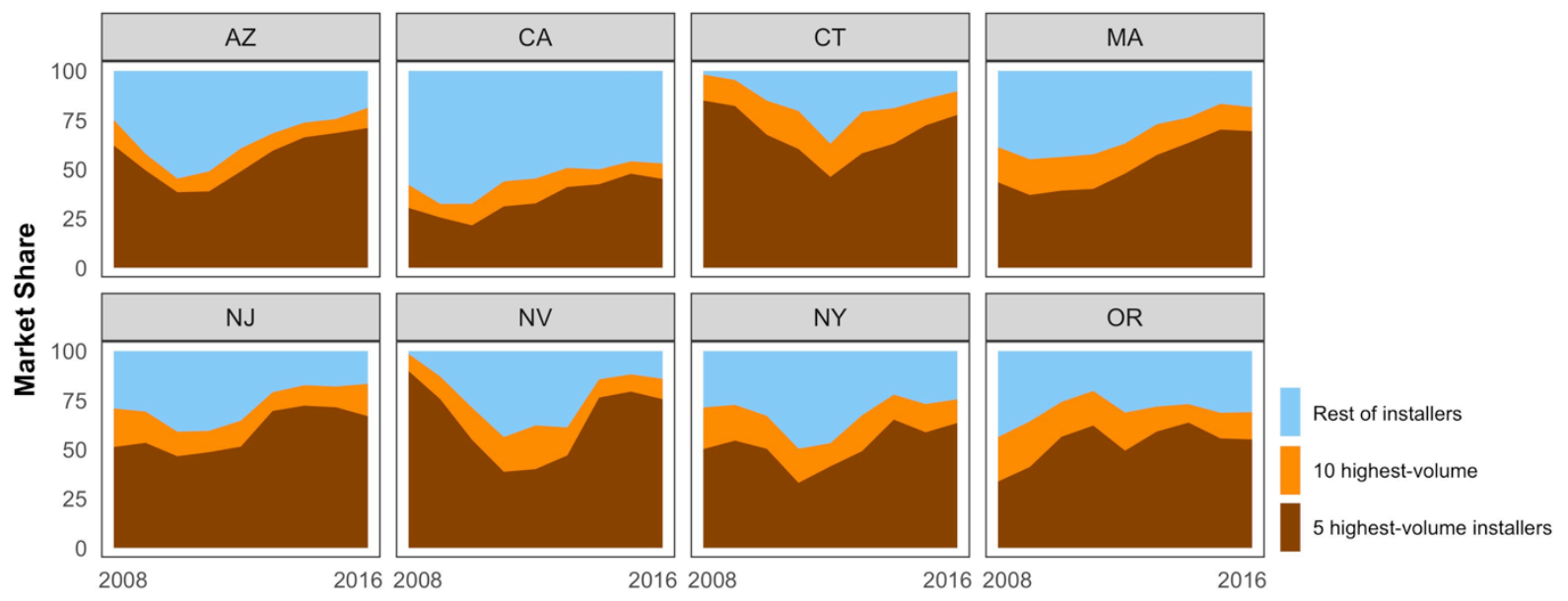

Figure 8. Market shares of highest-volume 5 and 10 installers by state, for the eight states with the most installations in the data set, 2008-2016

In terms of HHI, the U.S. residential PV installation industry appears to have at first become less concentrated in the early 2000s before beginning to concentrate around 2012 (Figure 9). The nationwide HHI grew from 0.01 in 2010 to a peak of 0.13 in 2015, before falling to 0.09 in 2016 . The increase in concentration is explored in depth in Section 4. Comparing Figure 9 with the Lorenz curves in Figure 6 shows that decreasing concentration from 2000 to about 2006 was not due to a redistribution of market shares but primarily to strong market entry over this period. Even at peak concentration in 2015 , the industry classified as un-concentrated $(<0.15 \mathrm{HHI})$, according to the U.S. Department of Justice horizontal merger guidelines (U.S. DOJ 2010).

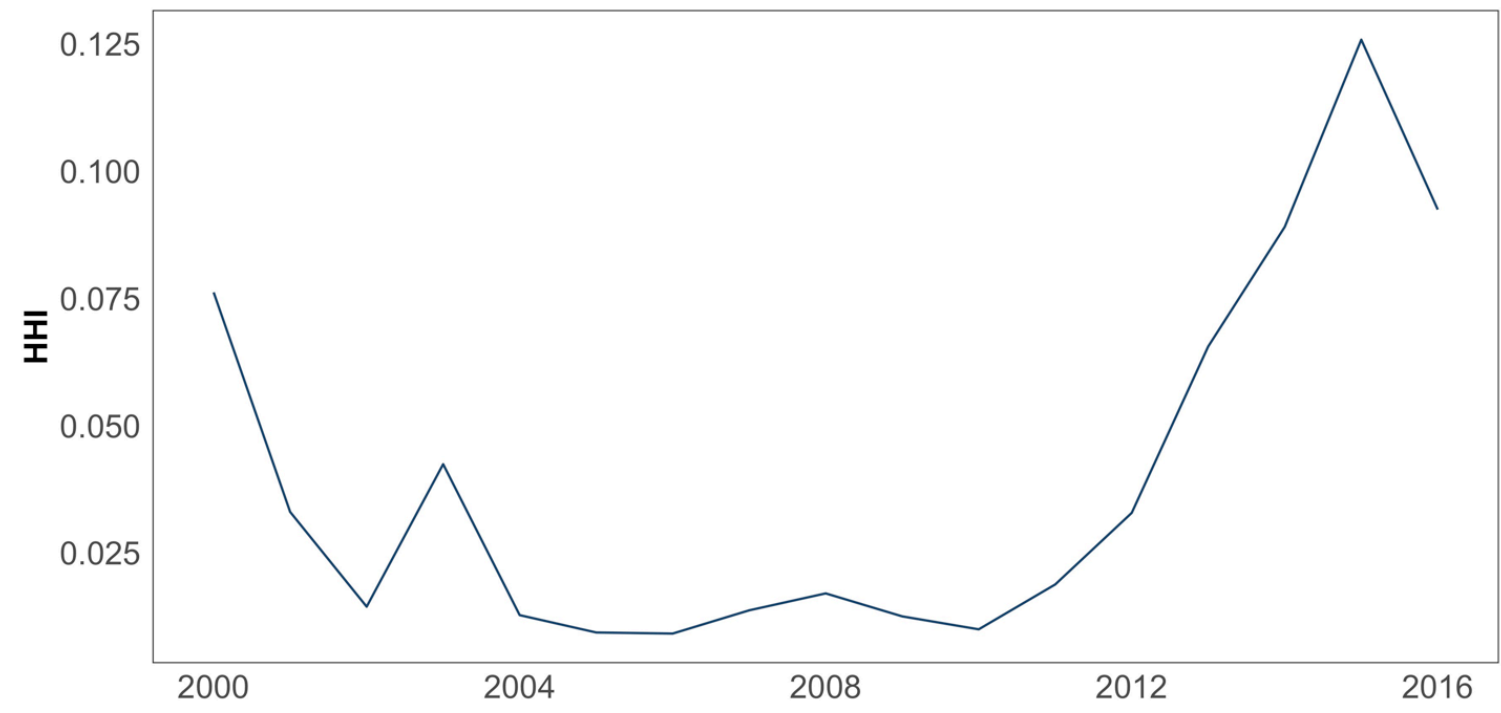

Figure 9. Residential PV installation industry HHI, 2000-2016 
Figure 10 plots HHI from 2008 to 2016 for the eight states with the most installations in the data set. Consistent with national trends, HHIs increased from 2012 to 2015 in all eight states, and decreased from 2015 to 2016 in every state except New York. The dramatic swing in Nevada reflects state-specific market dynamics; several high-volume installers entered this market around 2013 then left in 2016 in response to utility rate changes.
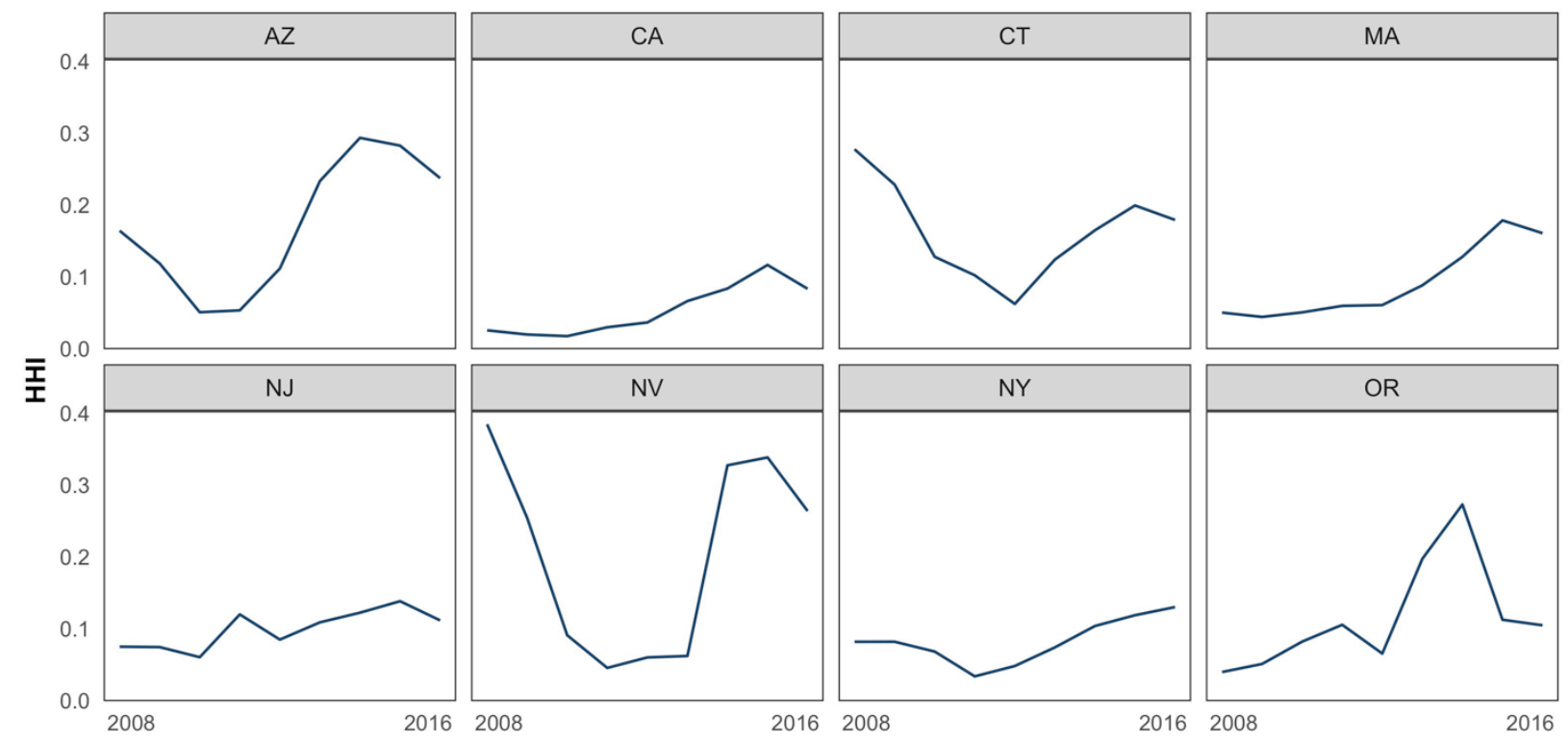

Figure 10. HHI for the eight states with the most installations in the data set, 2008-2016

Figure 11 plots HHI over time for the eight counties with the most installations to date, which are all in California. The county-level trends are consistent with the national- and state-level trends; HHIs increased from 2012 to 2015 in all eight counties and decreased from 2015 to 2016 in six of the eight counties. HHIs increased from 2010 to 2015 and decreased from 2015 to 2016 in about $60 \%$ of all counties in the data set with more than 100 systems installed. 

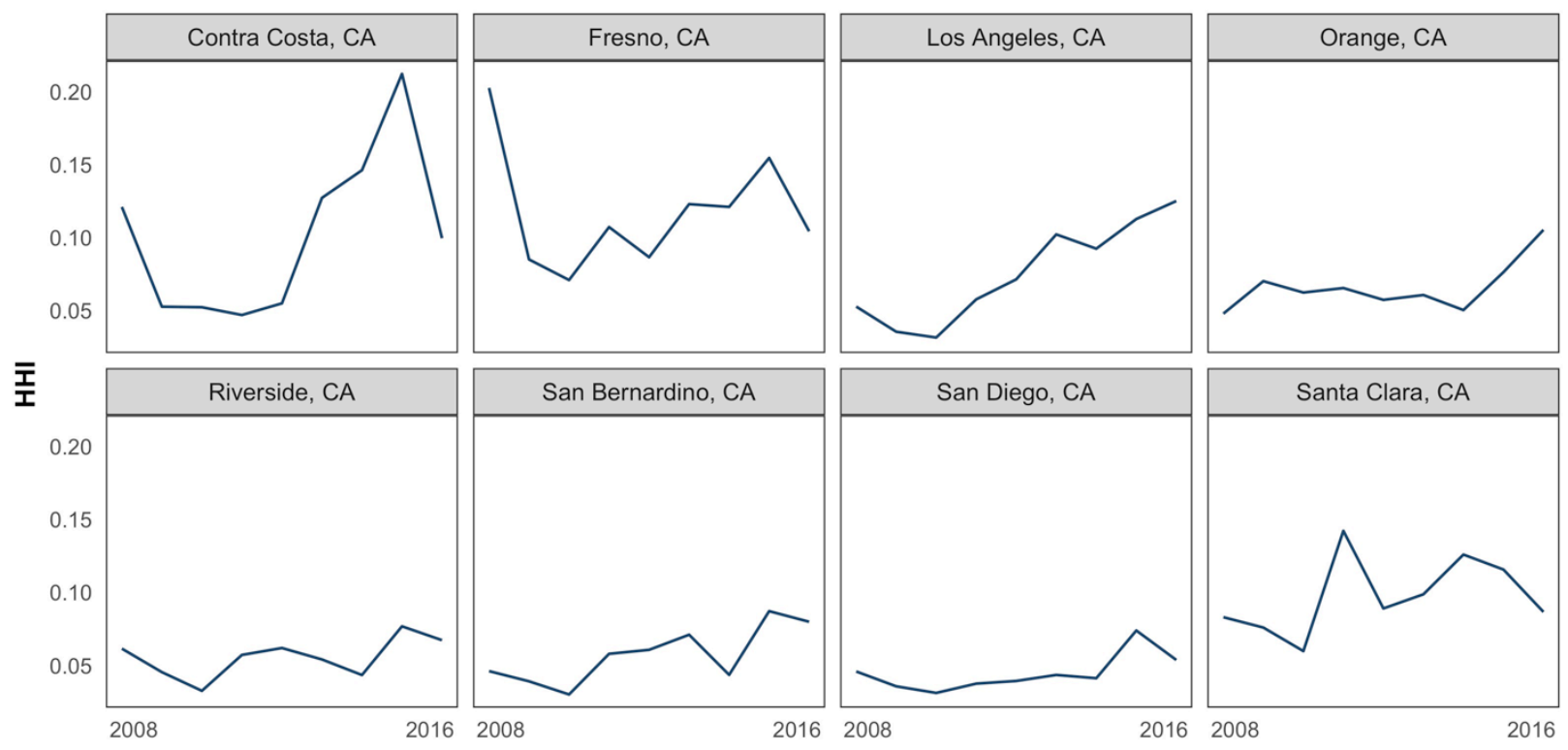

Figure 11. HHI for the eight counties with the most installations in the data set, 2008-2016

Figure 12 plots HHI over time for the eight largest local markets. Each local market is labeled with the largest city within that market, but local markets may consist of multiple cities or fractions of a city. Unlike counties, where market size is skewed toward the large geographic areas of California counties (Figure 11), six of the largest markets are outside California. Consistent with national trends, HHIs increased from 2012 to 2015 and decreased from 2015 to 2016 in seven of the eight markets.
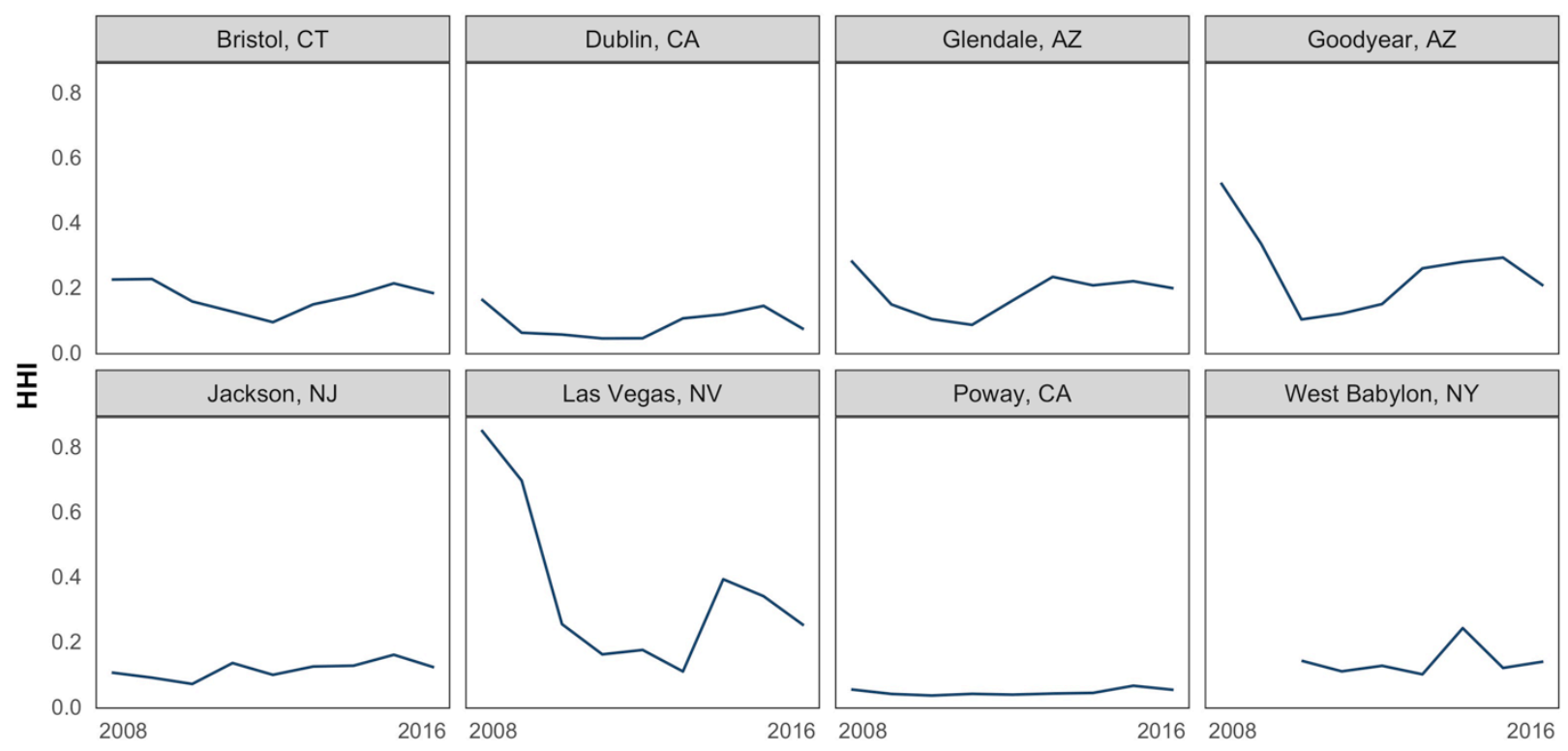

Figure 12. HHI for the eight local markets with the most installations in the data set, 2008-2016 
Finally, Figure 13 illustrates changes in HHI from 2012 to 2015 (left) and from 2015 to 2016 (right) for all 961 local markets in the data set. HHIs increased in about $53 \%$ of local markets from 2012 to 2015 and decreased in about $61 \%$ of local markets from 2015 to 2016 . These trends seem stronger in western states than eastern states. About $68 \%$ of western markets (Arizona, California, New Mexico, Nevada, Oregon, and Texas) saw increasing HHI from 2012 to 2015, compared with about $40 \%$ of eastern markets. Similarly, about $68 \%$ of western markets saw decreasing HHI from 2015 to 2016, compared with 55\% of eastern markets.

$\Delta$ HHI (2012-2015)

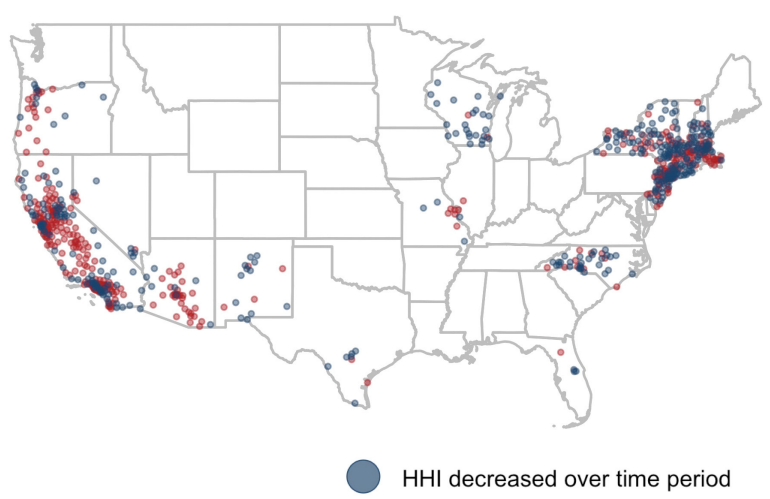

$\Delta$ HHI (2015-2016)

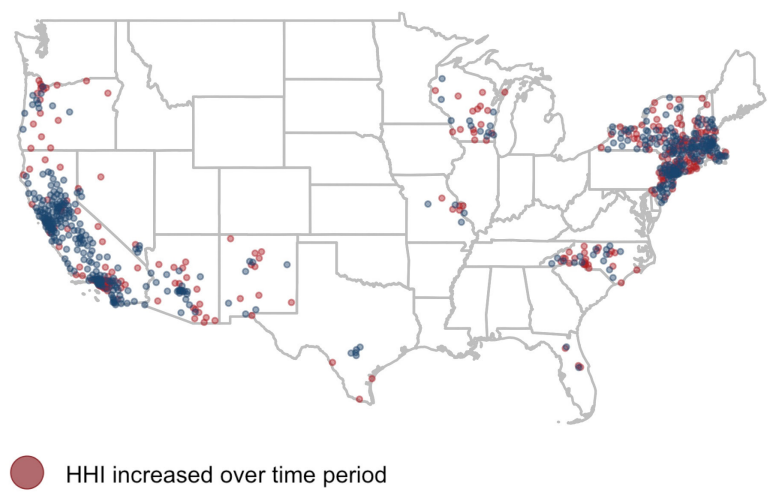

Figure 13. HHI changes by local market from 2012 to 2015 (left) and from 2015 to 2016 (right)

To summarize, Lorenz curves and market concentration measurements (HHI) suggest the U.S. residential PV installation industry has gone through four phases of market structure since 2000:

- 2000-2004: Relative to the current residential PV installation industry, few companies competed in the early industry in the early 2000 s. HHI measurements were initially high, because relatively few competitors split up the market. HHI and the market shares of the industry's highest-volume installers fell throughout this period, suggesting the industry became less concentrated as a result of market entry.

- 2004-2012: By 2004, the market shares of the industry's highest-volume installers had stabilized and remained relatively constant through 2010 . HHI similarly remained relatively stable from 2004 to 2012 . The data indicate that the industry's high-volume installers were able to maintain market share despite ongoing market entry, although these companies were unable to increase market share over this period.

- 2012-2015: The industry became increasingly concentrated between 2012 and 2015, according to the market shares of the highest-volume installers and HHI estimates under all market definitions. In other words, a subset of high-volume installers increased market share from 2012 to 2015.

- 2015-2016: The residential PV industry became less concentrated from 2015 to 2016 according to HHI estimates under all market definitions. This trend has been observed elsewhere (Perea et al. 2017), but it is too early to understand whether the trend will continue or whether it is an anomalous observation based on one year of data.

Possible explanations for these trends are explored in Section 4. 


\section{Role of Customer Financing in the Evolving PV Market Structure}

The U.S. residential PV installation industry has become increasingly concentrated over time, although market concentration declined from 2015 to 2016. Increasing market concentration is likely associated with several factors. Among these factors is the emergence of customer financing options (MIT 2015; Nemet et al. 2017; Litvak 2017; Perea et al. 2017; Pless et al. 2017). This section provides a descriptive analysis of the relationship between market concentration and the emergence of alternative customer financing models.

\subsection{Background: Customer Financing Options}

Residential PV customers may buy their own systems or host a system under a third-partyownership (TPO) arrangement. These customer ownership models have produced three types of residential PV transactions. First, an installer may sell a system directly to a homeowner. In this case, the homeowner pays the full installation cost and owns the PV system. Second, an installer may sell services to a non-integrated third-party provider (TPP). In this case, the non-integrated TPP buys the system from the installer and offers some type of TPO transaction to the homeowner. The homeowner pays the TPP through periodic lease or power purchase agreement payments. Third, an integrated TPP both installs and owns the system, providing installation and TPO services to the homeowner.

The ability to finance PV systems with low or no upfront costs makes TPO an attractive option for many customers (Rai and Sigrin 2013; Davidson et al. 2015; Rai et al. 2016). Utility regulations that treated TPPs as utilities hindered the TPO model in the early 2000s. However, policy reforms that exempted TPPs from utility regulations in some states resulted in a rapid increase in TPO system deployment beginning in the late 2000s (Drury et al. 2012). By 2015, more than half of residential PV systems installed used the TPO model, including more than $60 \%$ of systems in California (Litvak 2017; Perea et al. 2017). However, falling PV system prices have resulted in a shift back toward customer ownership in recent years (Perea et al. 2017).

Non-integrated and especially integrated TPPs tend to be relatively high-volume PV companies (MIT 2015; Nemet et al. 2017; Litvak 2017; Perea et al. 2017; Pless et al. 2017). The association between TPO and high-volume companies is due in part to the reliance of PV incentives on tax equity. Residential PV systems in the United States are eligible for federal tax incentives worth roughly half of installed system costs. ${ }^{7}$ However, most TPPs have insufficient tax bases to monetize these incentives fully. As a result, TPPs have sought tax equity to monetize available tax incentives. In a tax-equity transaction, a TPP sells some portion of a system to a tax-equity investor such as a bank. The tax-equity investor uses its tax basis to monetize the tax incentives and conveys these incentives back to the TPP while retaining some fee. Tax-equity investors typically require asset portfolios on the order of tens of millions of dollars (MIT 2015). Taxequity access is thus limited to high-volume residential PV companies that can aggregate thousands of residential PV systems to transact with tax-equity investors. In other words, the reliance on tax equity effectively limits TPO markets to higher-volume companies.

\footnotetext{
${ }^{7}$ The combination of the federal investment tax credit (30\% of installation costs) and accelerated depreciation under the modified accelerated recovery system generally offset around half of upfront costs.
} 
The TTS data illustrate how high-volume installers have led the emergence of the TPO model. In 2016, high-volume installers (those installing more than 1,000 systems per year) accounted for about $32 \%$ of customer-owned systems but $82 \%$ of TPO systems. Further, only about $21 \%$ of installers installed a TPO system in 2016, although about $56 \%$ of all systems were TPO systems. In other words, relatively few installers installed TPO systems despite their popularity with customers. Figure 14 illustrates how a relatively small number of installers have driven the emerging TPO market. By 2012, the TPO model accounted for over $60 \%$ of the residential PV market, yet less than $10 \%$ of installers used the TPO model in over half of their installations. By 2015, more than 3,000 installers installed predominantly customer-owned systems, while only about 300 installers installed predominantly TPO systems.

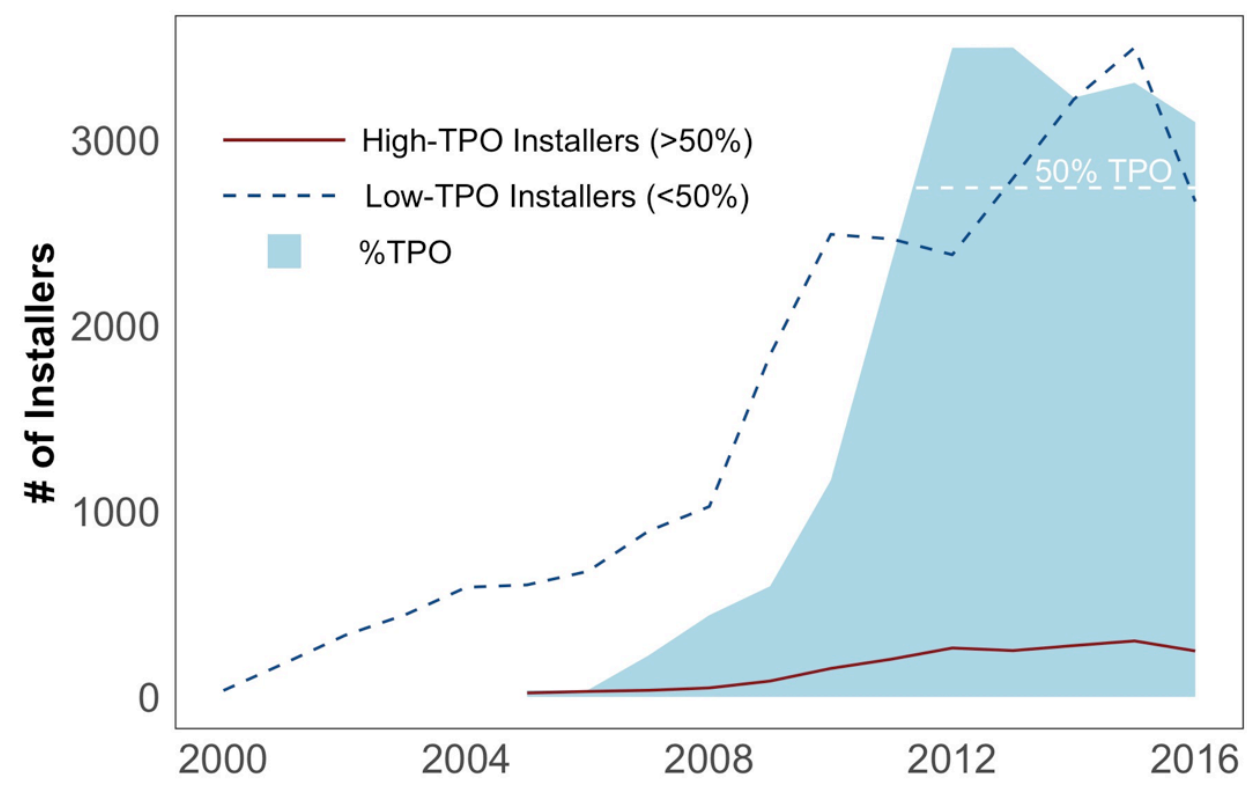

Figure 14. Number of installers using the TPO model by year, 2000-2016

\subsection{Analysis: Relationship Between Market Structure and Customer Finance}

Trends in the data are consistent with the hypothesis that market concentration is associated with the emergence of TPO products. The period of increasing market concentration from roughly 2012 to 2015 corresponds with a period of high TPO penetration into the residential PV market (Figure 15). Furthermore, increasing market concentration appears to have lagged behind increased TPO penetration, suggesting that the emergence of the TPO model supported increasing market concentration, rather than the inverse relationship. Falling market concentration from 2015 to 2016 corresponds with a period of falling TPO shares of the residential PV market. 


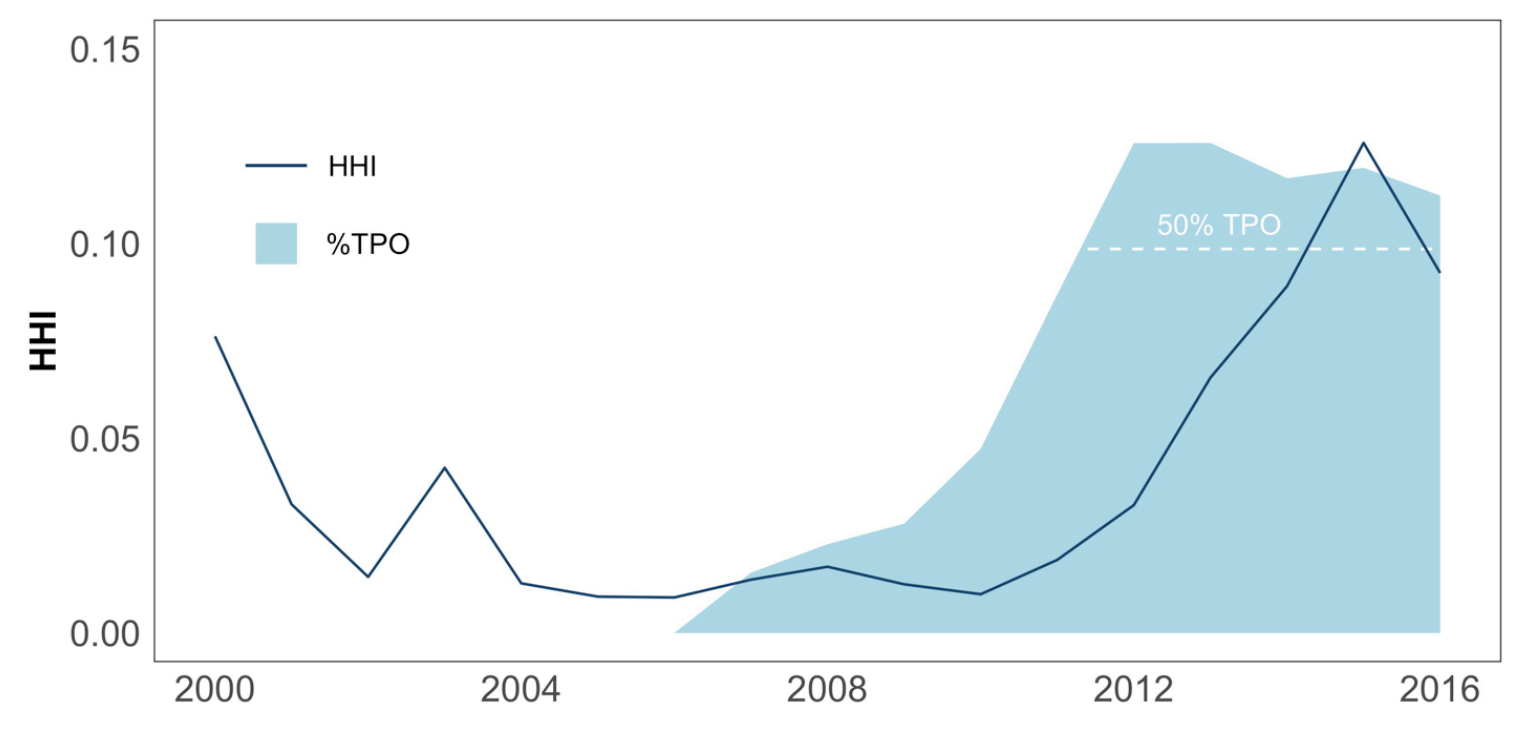

Figure 15. $\mathrm{HHI}$ and \%TPO, 2000-2016

Similar relationships between rising TPO penetration and increasing market concentration are found at the state level (Figure 16). Similar to national trends, increasing market concentration appears to have lagged behind increased TPO penetration by one or two years in most states.
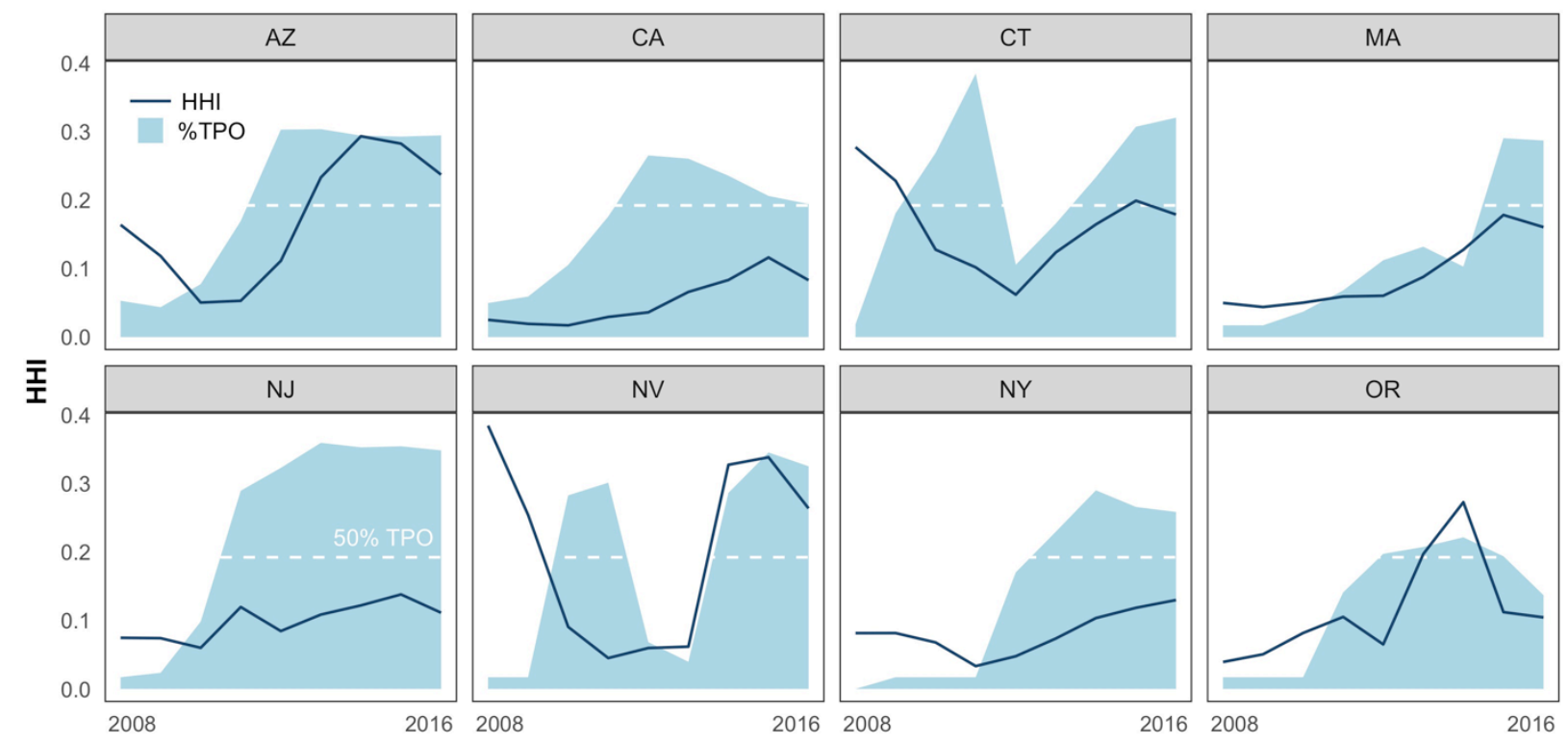

Figure 16. $\mathrm{HHI}$ and \%TPO by state, 2008-2016

Similar lags between increasing TPO penetration and increased market concentration are also evident at the local market level (Figure 17). HHI increases appears to have lagged behind TPO penetration in markets in Bristol, Connecticut; Dublin, California; Glendale, Arizona; Goodyear, Arizona; and West Babylon, New York. HHI appears to have increased sharply and contemporaneously with a rapid increase in TPO penetration in Las Vegas. In contrast, HHIs showed relatively little response to increasing TPO penetration in Jackson, New Jersey, and Poway, California. 

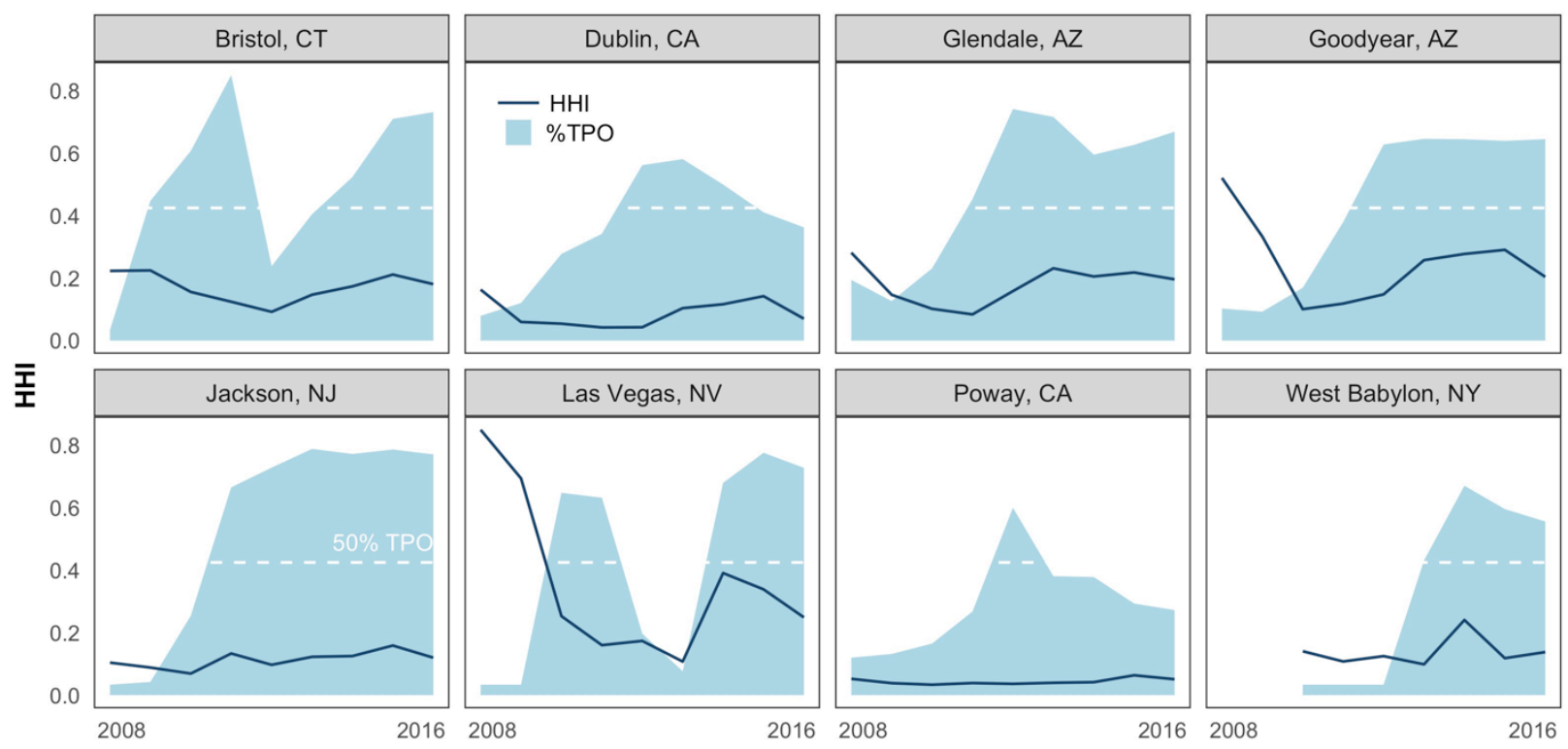

Figure 17. HHI and \%TPO by local market, 2008-2016

Figure 18 provides further descriptive evidence of the relationship between market concentration and the TPO model. The left pane of Figure 18 treats TPO and non-TPO PV systems as two separate markets. HHIs for non-TPO systems fell from 2000 to 2010, and they have remained relatively low through 2016, with no evidence of increasing concentration from 2012 to 2015. In contrast, after an initial reduction in HHI from 2004 to 2008, HHIs for TPO systems rose from 2008 through 2015. The right pane of Figure 18 separates states according to the percentage of installed systems that are TPO systems. HHIs in states with low $(<10 \%)$ TPO penetration have remained relatively low since 2008, with no visual increase from 2012 to 2015. In contrast, HHIs in states with high (> 10\%) TPO penetration steadily increased from 2012 to 2015, before declining slightly in 2016. These results indicate that the phenomenon of increasing PV market concentration is largely limited to TPO markets. Therefore, the recent reduction in concentration may similarly be due to a shift toward customer ownership, indicating that high-volume installers may not have the same competitive advantages in customer-owned systems as these installers have in TPO systems. 
HHI by TPO and non-TPO Systems

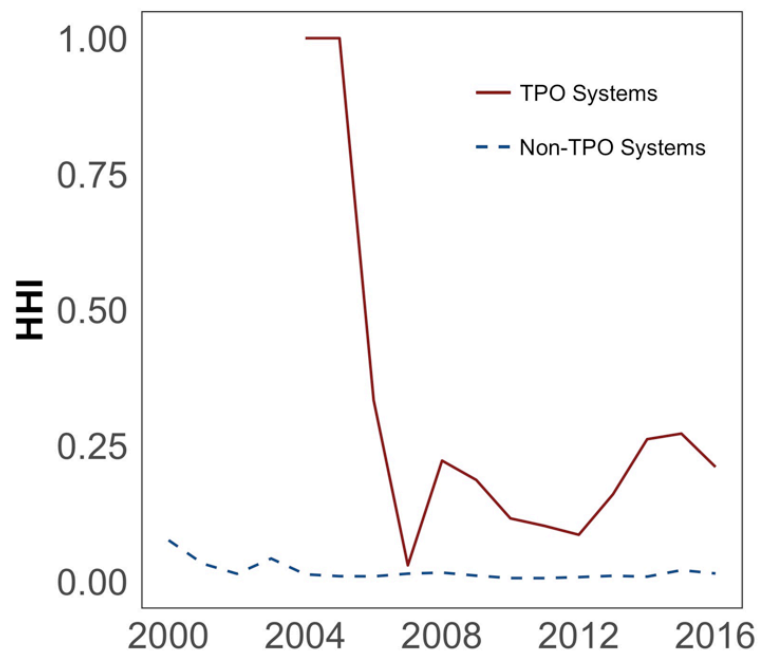

$\mathrm{HHI}$ by High- and Low-TPO States

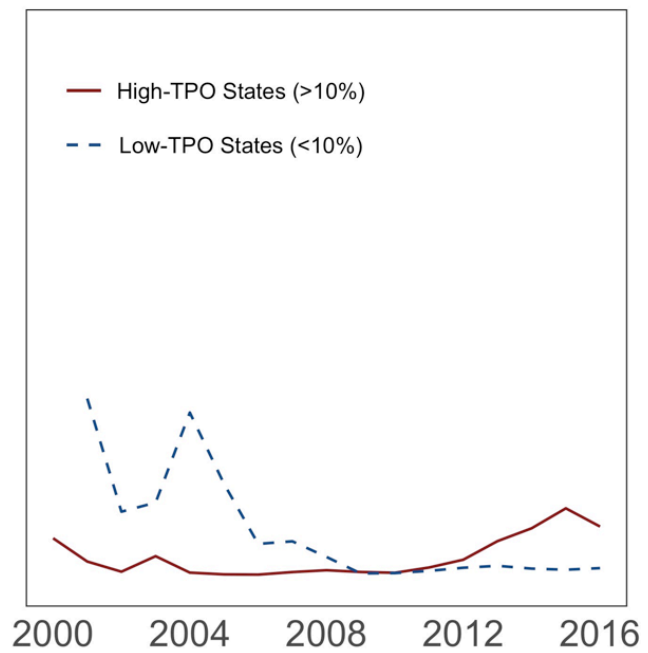

Figure 18. HHI for TPO and non-TPO systems (left) and in high- and low-TPO states (right)

The left pane of Figure 19 depicts Lorenz curves for TPO and non-TPO systems in 2016. The TPO Lorenz curve is further from market parity than the non-TPO curve, illustrating that sales of TPO systems were relatively more concentrated in higher-volume installers than sales of nonTPO systems. The right two panes in Figure 19 show how TPO sales concentrated more significantly from 2012 to 2016 than did sales of customer-owned systems.
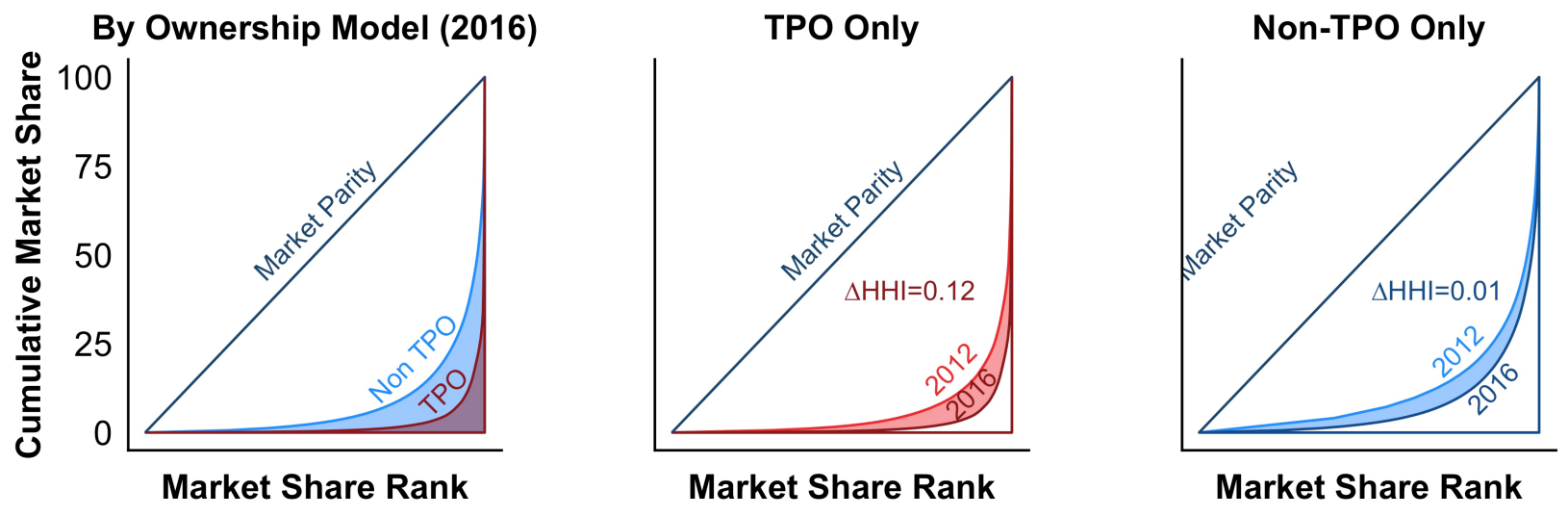

Figure 19. Lorenz curves for TPO and non-TPO systems

The data provide descriptive evidence that emergence of the TPO model contributed to increasing residential PV market concentration. Falling prices are likely another key contributing factor to residential PV market structure formation. Median installed prices for residential PV systems declined from $\$ 11.9 / \mathrm{W}$ to $\$ 5.4 / \mathrm{W}$ from 2000 to 2012 , and to $\$ 4.0 / \mathrm{W}$ by 2016 (Barbose and Darghouth 2017). Some high-cost installers that entered the market during a high-price period may have been forced to exit the market as prices declined. Such high-cost exits ultimately would cede market share to lower-cost installers. Thus, market concentration may also indicate market evolution, with installers accumulating market share through innovation and low costs. The relationship between PV prices and market structure is an area for further research. 


\section{Discussion and Conclusion}

The U.S. residential PV installation market has become more concentrated over time. However, the concentration does not imply that some high-volume companies have grown at the expense of small companies. The period of increasing market concentration from 2012 to 2015 coincided with a significant expansion of the residential PV market. Figure 20 depicts trends for installers that had entered the industry in 2012 or earlier. The left pane of Figure 20 clearly shows that the highest-volume installers increased market share considerably from 2012 to 2015 . However, the right pane of Figure 20 shows that other active installers continued to increase sales volumes through 2015 despite losing market share. In other words, market concentration during this period was not a zero-sum game, as the growing market allowed smaller installers to increase sales volumes even while losing market share. The drop in volumes in 2016 corresponds with a drop in installations in the data set overall for 2016.
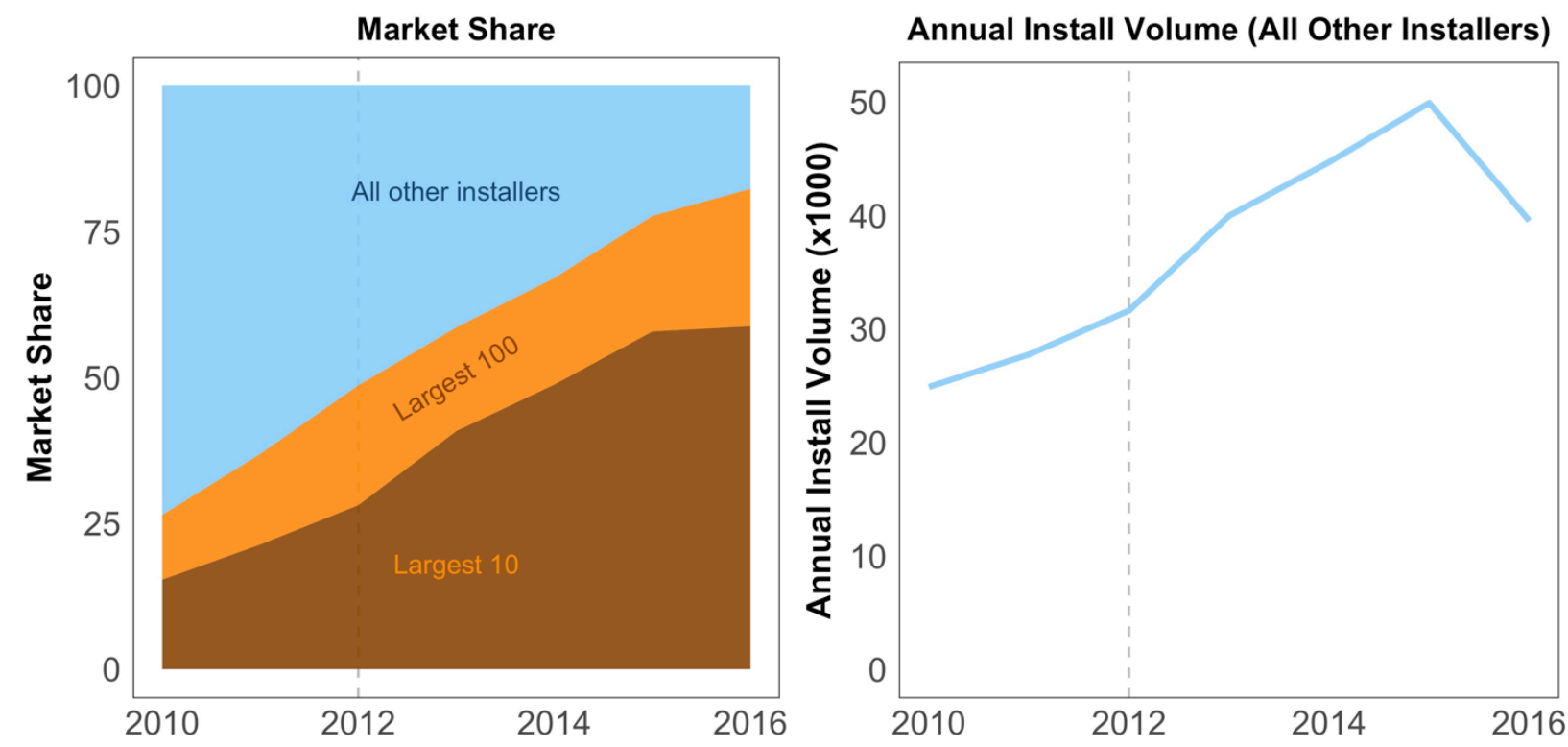

Figure 20. Market shares of all installers active before 2013 (left) and annual installation volumes of those installers outside the highest-volume 100 (right)

The relationship between market concentration and market size in the U.S. residential PV industry remains an ongoing area of research, and plausible arguments of causality run in either direction. The emergence of the TPO model, led by high-volume installers, resulted in a significant expansion of the residential market (Drury et al. 2012; Rai and Sigrin 2013). Thus, increasing market concentration associated with the TPO model may have facilitated an expansion of the residential PV market. Further, several studies indicate that market concentration may generate lower market prices (Gillingham et al. 2016; Pless et al. 2017). At the same time, increasing market concentration may allow some high-volume installers to exercise more market power than lower-volume installers, resulting in higher prices and possibly stymying PV adoption (Bollinger and Gillingham 2014, O’Shaughnessy and Margolis 2017a). Alternatively, high-volume installers appear to experience diseconomies of scale in terms of customer acquisition (Fu et al. 2017; Mond 2017), suggesting that PV market concentration may increase soft costs. The effects of market structure on market size and prices are areas of future research. 
The residential PV industry's increasing concentration over time does not necessarily imply that the industry has become less competitive. Indeed, several studies show that market prices can be lower in more concentrated PV markets, possibly because high-volume installers engage in price wars or exert downward price pressures on smaller installers (Gillingham et al. 2016; Nemet et al. 2017; Pless et al. 2017). The residential PV industry is also evolving as customers find new ways to procure PV. For instance, several third-party quote providers have emerged that provide platforms connecting customers to installers for the purposes of finding quotes. These quote platforms foster competitive pricing, allowing customers to obtain quotes from several installers and thus benefit from lower prices (O'Shaughnessy and Margolis 2017b).

Finally, the objective of this study is to describe trends in the residential PV installation industry's market structure rather than analyze the implications of those trends. The implications of market concentration are not necessarily unambiguously positive or negative for the residential PV industry. The potential accumulation of market power among high-volume installers could be a policy concern because of the implications for PV soft costs. At the same time, market concentration may simply reflect market maturation and the accrual of market share among the industry's most innovative and successful companies, in which case policies to reduce concentration could stunt further industry growth.

To conclude, about 8,700 companies installed at least one residential PV system from 2000 to 2016. In 2016, the U.S. residential PV industry consisted of about 2,900 installers. The market has become increasingly concentrated over time as a group of high-volume installers has gained market share. By 2016, less than 1\% of installers installed more than 1,000 systems per year, but these high-volume installers accounted for about $60 \%$ of all systems installed. The data provide descriptive evidence that the emergence of the TPO model contributed to this market concentration. The effects of this market concentration are areas for future research. 


\section{References}

Barbose, G., and N. Darghouth. 2017. Tracking the Sun X: The Installed Price of Residential and Non-Residential Photovoltaic Systems in the United States. Berkeley, CA: Lawrence Berkeley National Laboratory.

Bollinger, B., and K. Gillingham. 2014. "Learning-by-Doing in Solar Photovoltaic Installations." Working paper, available at SSRN: http://dx.doi.org/10.2139/ssrn.2342406.

Brooks, G. 1995. “Defining Market Boundaries.” Strategic Management Journal 16:535-549.

Davidson, C., D. Steinberg, and R. Margolis. 2015. "Exploring the Market for Third-PartyOwned Residential Photovoltaic Systems: Insights from Lease and Power-Purchase Agreement Contract Structures and Costs in California.” Environmental Research Letters 10024006.

Davis, P., and E. Garces. 2010. Quantitative Techniques for Competition and Antitrust Analysis. Princeton, NJ: Princeton University Press.

Drury, E., M. Miller, C. Macal, D. Graziano, D. Heimiller, J. Ozik, and T. Perry. 2012. "The Transformation of Southern California's Residential Photovoltaics Market through Third-Party Ownership." Energy Policy 42:681-690.

Fu, R., D. Feldman, R. Margolis, M. Woodhouse, and K. Ardani. 2017. U.S. Solar Photovoltaic System Cost Benchmark: Q1 2017. NREL/TP-6A20-68925. Golden, CO: National Renewable Energy Laboratory.

Gillingham, K., H. Deng, R.H. Wiser, N. Darghouth, G. Nemet, G.L. Barbose, V. Rai, and C. Dong. 2016. "Deconstructing Solar Photovoltaic Pricing: The Role of Market Structure, Technology, and Policy." The Energy Journal 37(3):231-250.

Litvak, N. 2017. U.S. Residential Solar Update 2017. GTM Research.

Mond, A. 2017. U.S. Residential Solar PV Customer Acquisition 2017. GTM Research.

MIT (Massachusetts Institute of Technology). 2015. The Future of Solar Energy. MIT.

Nemet, G., E. O'Shaughnessy, N.R. Darghouth, R.H. Wiser, G.L. Barbose, K. Gillingham, and V. Rai. 2017. "Characteristics of Low-Priced Photovoltaic Systems in the United States." Applied Energy 187:501-513.

O’Shaughnessy, E., G. Nemet, and N. Darghouth. 2016. Using the Spatial Distribution of Installers to Define Solar Photovoltaic Markets. NREL/TP-6A20-66773. Golden, CO: National Renewable Energy Laboratory.

O’Shaughnessy, E., and R. Margolis. 2017a. Using Residential Solar PV Quote Data to Analyze the Relationship between Installer Pricing and Firm Size. NREL/TP-6A20-68010. Golden, CO: National Renewable Energy Laboratory. 
O'Shaughnessy, E., and R. Margolis. 2017b. The Value of Transparency in Distributed Solar PV Markets. NREL/TP-6A20-70095. Golden, CO: National Renewable Energy Laboratory.

Perea, A., C. Honeyman, S. Kann, A. Mond, M. Shiao, J. Jones, S. Moskowitz, B. Gallagher, C. Smith, S. Rumery, A. Holm, K. O’Brien, and J. Baca. 2017. U.S. Solar Market Insight. GTM Research/Solar Energy Industries Association.

Pless, J., R. Langheim, C. Machak, H. Hellow, and B. Sigrin. 2017. The Price-Concentration Relationship in Early Residential Solar Third-Party Markets. NREL/TP-6A20-66784. Golden, CO: National Renewable Energy Laboratory.

Rai, V., and B. Sigrin. 2013. "Diffusions of Environmentally-Friendly Energy Technologies: Buy versus Lease Differences in Residential PV Markets." Environmental Research Letters 8014022 .

Rai, V., D.C. Reeves, and R. Margolis. 2016. "Overcoming Barriers and Uncertainties in the Adoption of Residential Solar PV. Renewable Energy 89:498-505.

Stigler, G., and R. Sherwin. 1985. "The Extent of the Market.” Journal of Law \& Economics 28:555-585.

Solar Foundation. 2017. 2016 National Solar Jobs Census. The Solar Foundation.

Tirole, J. 1988. “The Theory of Industrial Organization.” Cambridge, MA: The MIT Press.

U.S. DOJ (U.S. Department of Justice). 2010. Horizontal Merger Guidelines. U.S. Department of Justice and Federal Trade Commission. 


\section{Key Report Contacts}

\author{
Eric 0'Shaughnessy \\ National Renewable Energy Laboratory \\ eric.oshaughnessy@nrel.gov
}

\section{Acknowledgments}

This work was supported by the Solar Energy Technologies Office at the U.S. Department of Energy. The author would like to thank the following individuals and organizations for their thoughtful review of this work: Naïm Darghouth (Lawrence Berkeley National Laboratory), Ran Fu (NREL), Ed Gilliland (The Solar Foundation), and Greg Nemet (University of Wisconsin-Madison). The author would like to thank Mike Meshek (NREL) and Jarrett Zuboy (consultant) for editorial support. The author would also like to acknowledge the efforts of the many contributors to Lawrence Berkeley National Laboratory's Tracking the Sun data set, which made this study possible.

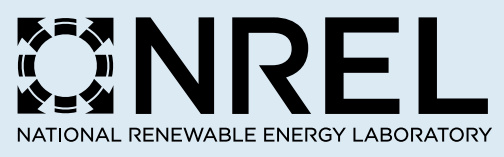

NREL is a national laboratory of the U.S. Department of Energy, Office of Energy Efficiency and Renewable Energy, operated by the Alliance for Sustainable Energy, LLC.

NREL/TP-6A20-70545 • January 2018

NREL prints on paper that contains recycled content.

\section{Notice}

This report was prepared as an account of work sponsored by an agency of the United States government. Neither the United States government nor any agency thereof, nor any of their employees, makes any warranty, express or implied, or assumes any legal liability or responsibility for the accuracy, completeness, or usefulness of any information, apparatus, product, or process disclosed, or represents that its use would not infringe privately owned rights. Reference herein to any specific commercial product, process, or service by trade name, trademark, manufacturer, or otherwise does not necessarily constitute or imply its endorsement, recommendation, or favoring by the United States government or any agency thereof. The views and opinions of authors expressed herein do not necessarily state or reflect those of the United States government or any agency thereof.

This report is available at no cost from the National Renewable Energy Laboratory (NREL) at www.nrel.gov/publications.

Available electronically at SciTech Connect http:/www.osti.gov/scitech

Available for a processing fee to U.S. Department of Energy and its contractors, in paper, from:

U.S. Department of Energy

Office of Scientific and Technical Information

P.0. Box 62

Oak Ridge, TN 37831-0062

OSTI http://www.osti.gov

Phone: 865.576.8401

Fax: 865.576.5728

Email: reports@osti.gov

Available for sale to the public, in paper, from:

U.S. Department of Commerce

National Technical Information Service

5301 Shawnee Road

Alexandria, VA 22312

NTIS http://www.ntis.gov

Phone: 800.553 .6847 or 703.605 .6000

Fax: 703.605 .6900

Email: orders@ntis.gov 